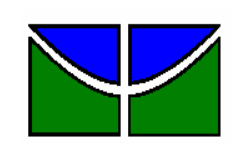

UNIVERSIDADE DE BRASÍLIA - UnB

FACULDADE DE ECONOMIA, ADMINISTRAÇÃO, CONTABILIDADE E CIÊNCIA DA INFORMAÇÃO E DOCUMENTAÇÃO (FACE)

PROGRAMA DE PÓS-GRADUAÇÃO EM ADMINISTRAÇÃO - PPGA

I CURSO DE ESPECIALIZAÇÃO EM GESTÃO DE PROGRAMAS E PROJETOS

EDUCACIONAIS

Rosemary Pereira de Oliveira Montalvão

ESTUDO SOBRE A POLÍTICA EDUCACIONAL IMPLEMENTADA PELO PLANO DE DESENVOLVIMENTO DA EDUCAÇÃO

Brasília - DF

2008 
Rosemary Pereira de Oliveira Montalvão

\section{ESTUDO SOBRE A POLÍTICA EDUCACIONAL IMPLEMENTADA PELO PLANO DE DESENVOLVIMENTO DA EDUCAÇÃO}

Trabalho de monografia apresentado como quesito necessário à conclusão do Curso em Pós-Graduação Lato Sensu da Universidade de Brasília, Faculdade de Economia, Administração, Contabilidade e Ciência da Informação e Documentação, Programa de Pós-Graduação em Administração, para obtenção do título de Especialista em Gestão de Programas e Projetos Educacionais.

Orientador: Professor Doutor Bernardo Kipnis 
A Deus, que me proporcionou mais este momento de crescimento em minha vida.

A meu pai, que sempre foi e será minha inspiração, o qual partiu para Deus durante a realização de meu curso.

A minha mãe, Doralice, e a meus irmãos, Isac, Lindomar, Lindon Johnson, que são muito importantes para mim.

A meu marido, José Nogueira Montalvão, e a minha filha, Jacqueline, que são meus companheiros de batalha. 


\section{AGRADECIMENTOS}

Aos meus pais, que sempre me incentivaram a estudar, agradeço pela dedicação, pela paciência e por acreditarem no meu potencial.

Ao professor doutor Bernardo Kipnis, por ter me orientado e dedicado parte do seu precioso tempo a este trabalho, agradeço pela sabedoria e pelo profissionalismo.

Aos colegas de turma e do FNDE que me apoiaram e que, com suas importantes sugestões, engrandeceram este trabalho.

Aos professores, pela colaboração e pelo apoio nas horas mais difíceis.

Aos funcionários do Programa de Pós-Graduação em Administração da Universidade de Brasília (UnB), pela eficiência e pelo respeito aos alunos.

Aos meus chefes, pela compreensão nos momentos em que precisava me ausentar do serviço.

Em especial, a Weber Gomes de Sousa, um amigo ímpar.

E a todos os que colaboraram em entrevistas e estudos e que dispuseram de seu tempo, valorizando este trabalho, o meu reconhecimento. 
As armas da crítica não podem, de fato, substituir a crítica das armas: a força material tem de ser deposta por força material, mas a teoria também se converte em força material uma vez que se apossa dos homens. A teoria é capaz de prender os homens desde que demonstre sua verdade face ao homem, desde que se torne radical. Ser radical é atacar o problema em suas raízes. 


\section{RESUMO}

Este trabalho analisou a política do Ministério da Educação implementada por meio do Plano de Desenvolvimento da Educação (PDE), buscando identificar suas bases teóricas e fundamentos filosóficos, bem como sua evolução desde a implantação, em 2007, até outubro de 2008, a partir da revisão teórica de algumas políticas educacionais adotadas no Brasil nas últimas décadas, confrontando-as com a atual política implementada pelo Ministério. Fundamentado na documentação que criou o PDE e com base em dados obtidos no âmbito do Fundo Nacional de Desenvolvimento da Educação (FNDE), um dos órgãos executores do plano, este estudo identificou, descreveu e caracterizou a política do PDE, focando o Programa Nacional de Reestruturação e Aparelhagem da Rede Escolar Pública de Educação Infantil (ProInfancia) e seus resultados. Tendo como base metodológica o estudo de caso, a pesquisa documental possibilitou a constatação, a partir da análise do atendimento à educação infantil, no âmbito do FNDE, de que os recursos destinados a essa etapa de ensino não vêm sendo aplicados em sua totalidade nos últimos dez anos, por sofrer constante contingenciamento orçamentário. Tal fato prejudicou o atendimento a essa clientela por vários anos. Ainda que esse atendimento seja considerado de vital importância, pelo menos, nos textos legais, na prática, não se observa essa priorização. Nesse sentido, o PDE merece destaque pela proposta do ProInfancia, por meio do qual a educação infantil está sendo atendida em uma de suas maiores necessidades, que é a ampliação da infra-estrutura e de equipamentos para escolascreches, com a aplicação de um volume considerável de recursos. O estudo revelou que, apesar do esforço da União em repassar recursos correspondentes a $80 \%$ do previsto para serem aplicados até 2010, a execução física das obras pelos municípios não ocorre com a mesma agilidade. Identificou a necessidade do comprometimento efetivo de todos os atores envolvidos, como todos os municípios e estados da Federação. Finalmente, revela que o modo de priorização adotado pelo PDE, o Î́ndice de Desenvolvimento da Educação Básica (Ideb), apesar de representar um avanço em termos de indicador para a educação, já dá indícios de que não pode responder, sozinho, a todas as demandas da educação em seus vários aspectos.

Palavras-chave: Plano de Desenvolvimento da Educação; política pública; políticas educacionais; Educação; Educação infantil. 


\begin{abstract}
The present study analyzed the Ministry of Education policy implemented by the Education Development Plan (PDE) aiming at identifying its theoretical and philosophical rationale as well as its evolution since its beginning, in 2007, through October 2008. In order to do so, it carried out a theoretical review of a few educational policies adopted in Brazil along the last decades and compared them with the ministry's current policy. Based on the documentation that created the PDE and on the data provided by the National Fund for the Development of Education (FNDE), which is one of the executing agencies of the plan, this study has identified, described and characterized PDE policy by focusing on the National Program for the Re-structuring and Procurement for the Child Education Public Schools (ProInfancia) and on its outcome. Following the case study methodology, the documentary research related to child education within the framework of the FNDE pointed out that the financial resources earmarked for this segment have not been used in their entirety along the last ten years as a result of frequent budget cuts. This has impaired assistance to that clientele for a number of years. Even though such assistance is considered crucial - at least in written legal texts -, that is not what is observed in practice. In this sense, the PDE is worth mentioning for its proposal of ProInfancia, the program that is able to fulfill one of the most critical needs of child education - amplification of the infrastructure and provision of equipment and supplies for schools functioning as day-care centers as well - by injecting a considerable amount of resources. The study has revealed that in spite of the federal government transferring up to $80 \%$ of the resources foreseen to be used until 2010, the physical execution of the works by the municipalities does not keep the same pace. It also has identified the need for an actual commitment from all actors involved, such as all municipalities and states of the country. It finally indicates that the means adopted by the PDE to detect priorities - the Basic Education Development Index (Ideb) - despite representing a step ahead in terms of an education indicator, has already demonstrated that it cannot satisfy by itself all educational demands.
\end{abstract}

Key words: Education Development Plan; public policy; educational policies; child education; education. 


\section{LISTA DE GRÁFICOS}

Gráfico 1 Distribuição de recursos para o ProInfancia em 2007 por região (em percentuais)

Gráfico 2 Distribuição de recursos para o ProInfancia em 2008 por região (em

milhões de reais) 


\section{LISTA DE TABELAS}

Tabela 1 Dotação e execução orçamentárias do FNDE de 1998 a 2007 (em milhões de reais)

Tabela 2 Distribuição de recursos para o ProInfancia em 2007-2008 por região (em

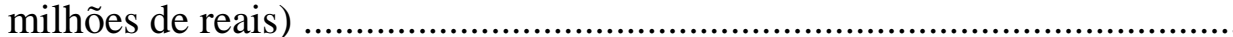




\section{LISTA DE QUADROS}

Quadro 1 Resultados e metas para o Ideb em 2005 e projeções para o Brasil

Quadro 2 Categorização das questões das entrevistas

Quadro 3 Temas referentes às categorias 36 


\section{LISTA DE SIGLAS}
ABNT
Associação Brasileira de Normas Técnicas
Caic
Centro de Atenção Integral à Criança
CGAAP Coordenação-Geral de Análise de Projetos
CGEST Coordenação-Geral de Infra-Estrutura Educacional
Ciep Centro Integrado de Educação Pública
Dirpe Diretoria de Programas e Projetos Educacionais
DOU Diário Oficial da União
EJA Educação de Jovens e Adultos
FNDE Fundo Nacional de Desenvolvimento da Educação
Fundef Fundo de Manutenção e Desenvolvimento do Ensino Fundamental e de Valorização do Magistério
Ideb Índice de Desenvolvimento da Educação Básica
IDH Índice de Desenvolvimento Humano
Inep Instituto Nacional de Estudos e Pesquisas Educacionais Anísio Teixeira
LDB Lei de Diretrizes e Bases da Educação
LSE Sistema de Levantamento da Situação Educacional
MEC Ministério da Educação
MPOG Ministério do Planejamento, Orçamento e Gestão
OCDE Organização para a Cooperação Econômica e o Desenvolvimento
PAC Plano de Aceleração do Crescimento
PAR Plano de Ações Articuladas
PDE Plano de Desenvolvimento da Educação
PNAE Programa Nacional de Alimentação Escolar
PNE Plano Nacional de Educação
PNLD Programa Nacional do Livro Didático
PPA Plano Plurianual
ProInfancia Programa Nacional de Reestruturação e Aparelhagem da Rede Escolar Pública de Educação Infantil
PTA Plano de Trabalho Anual
RCNEI Referencial Curricular Nacional de Educação Infantil
Saeb Sistema Nacional de Avaliação da Educação Básica 
SEB Secretaria de Educação Básica

Secad Secretaria de Educação Continuada, Alfabetização e Diversidade

Seesp Secretaria de Educação Especial

SEF Secretaria de Educação Fundamental

SigPlan Sistema de Informações Gerenciais e de Planejamento

Simec Sistema Integrado de Monitoramento do Ministério da Educação 


\section{SUMÁRIO}

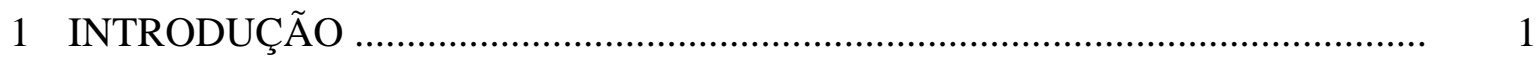

2 OBJETIVOS DO TRABALHO .....................................................................

2.1 Objetivo Geral ....................................................................................... 3

2.2 Objetivos Específicos ............................................................................... 3

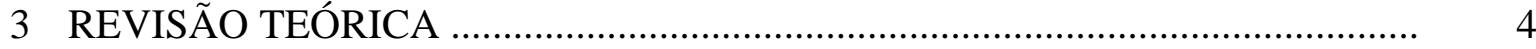

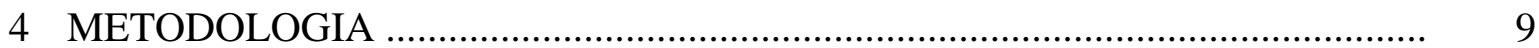

5 CARACTERIZAÇÃO DO MARCO REGULATÓRIO ......................................... 10

5.1 O Plano de Desenvolvimento da Educação (PDE) ..................................... 10

5.1.1 A proposta do Plano de Aceleração do Crescimento (PAC) ......... 10

5.1.2 O modelo anterior de atendimento às transferências voluntárias . 11

5.1.3 A proposta do Plano de Desenvolvimento da Educação (PDE) .... 12

5.1.4 A visão sistêmica em oposição à gerencialista .............................. 14

5.1.5 O Plano de Metas Compromisso Todos pela Educação ................ 17

5.1.6 O Plano de Ações Articuladas (PAR) ........................................... 20

5.1.7 O Índice de Desenvolvimento da Educação Básica (Ideb) ............ 21

5.1.8 O novo modelo de atendimento às transferências voluntárias ...... 23

5.2 O Programa Nacional de Reestruturação e Aparelhagem da Rede Escolar Pública de Educação Infantil (ProInfancia) .................................................. 24

5.2.1 O papel do Fundo Nacional de Desenvolvimento da Educação (FNDE) no PDE .................................................................... 26

5.2.2 O Sistema Integrado de Monitoramento do Ministério da Educação (Simec) ................................................................... 27

5.2.3 O atendimento da educação infantil pelo FNDE de 1998 a 2007 . 28

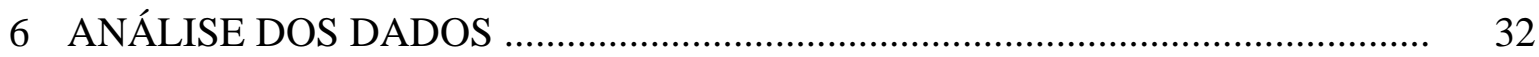

6.1 Resultados do ProInfancia .......................................................................... 32

6.2 Resultados das Entrevistas ........................................................................... 34

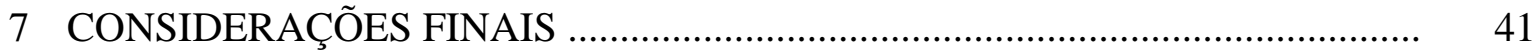

8 CONTRIBUIÇÕES E SUGESTÕES ................................................................. 43

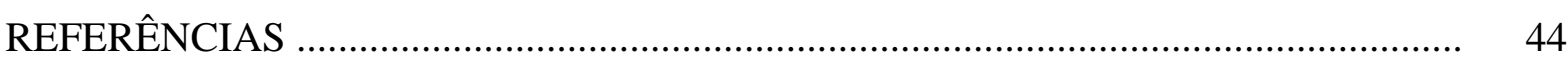

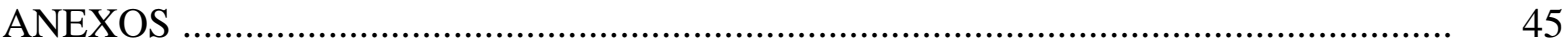




\section{1 - INTRODUÇÃO}

O conceito de educação relaciona-se intrinsecamente ao de ensino e aprendizagem. A educação é um fenômeno que ocorre nas mais diferentes sociedades, sendo ela a responsável pela sua manutenção e perpetuação mediante a transferência, às gerações futuras, dos meios culturais necessários à convivência do indivíduo no âmbito social. Está presente nos mais variados espaços de convívio social. Nesse sentido, educação coincide com os conceitos de socialização e endoculturação. Já a prática educativa formal, que acontece em instituições específicas, se dá de maneira intencional e com objetivos determinados, como no caso das escolas.

No Brasil, a educação escolar, desde a Independência, esteve ligada às políticas públicas, entendidas como forma de intervenção estatal na oferta e proteção de determinados direitos da cidadania. O Estado brasileiro apresenta-se como regulador no estabelecimento de uma política social dentro de uma concepção liberal clássica. Assim, a Constituição Federal traz como dever do Estado o oferecimento de educação pública e gratuita.

As políticas e os programas educacionais brasileiros buscam, ao longo da história, solucionar ou amenizar situações-problema que se apresentam em cada época. Porém, pode-se observar que os avanços, muitas vezes, são tímidos, e a descontinuidade das políticas públicas é uma das causas da dificuldade de se progredir nesse campo. Tal fato é confirmado pelos resultados das avaliações realizadas no âmbito do próprio governo.

O Sistema Nacional de Avaliação da Educação Básica (Saeb), por exemplo, acabou por demonstrar que a educação básica ainda está precária e precisa dar um salto de qualidade.

A partir da última década, o governo brasileiro vem demonstrando preocupação com a avaliação de forma geral, tanto no que diz respeito aos alunos quanto ao que toca às políticas e aos sistemas educacionais. Nesse sentido, o Plano Nacional de Educação (PNE) representa um avanço, se se levar em conta que determina metas a serem alcançadas, vinculadas a prazos que, embora, muitas vezes, não tenham sido cumpridos, até o momento, indicam um compromisso a ser honrado pelo governo com a sociedade.

Este trabalho tem como objetivo apresentar a política do Ministério da Educação (MEC) para o segundo mandato do governo Lula, configurada no Plano de Desenvolvimento da Educação (PDE). Trata-se de um estudo de caso, por meio do qual se pretende analisar a implantação e a implementação dessa política no período de 2007 a outubro de 2008, 
buscando uma reflexão sobre o que ela representa em termos de avanço para a educação no Brasil.

O estudo foi estruturado a partir de uma revisão teórica dos documentos que embasaram a criação do plano, bem como das bases filosóficas que o inspiraram e que perpassam a execução dos seus programas, especificamente, os relativos à educação infantil, em particular, o Programa Nacional de Reestruturação e Aquisição de Equipamentos para a Rede Escolar Pública de Educação infantil (ProInfancia), cuja implementação é de responsabilidade do Fundo Nacional de Desenvolvimento da Educação (FNDE). Pretendeu-se destacar as características do plano implantado no ano de 2007, no âmbito do Programa de Aceleração do Crescimento (PAC), política nacional de desenvolvimento adotada pelo governo atual. Também foi analisada a execução física e financeira, ou seja, a gestão dos recursos orçamentários disponibilizados para o ProInfancia. Justifica-se a escolha desse tema por se tratar de um dos principais programas do PDE gerido pelo FNDE, cujo alcance e resultados merecem destaque, e, ainda, pelo fato de a pesquisa poder ser feita em um campo mais próximo tanto no sentido do conhecimento institucional quanto de localização física da pesquisadora.

Cabe enfatizar que, ao se estudar uma política voltada para a educação, é preciso entender que as questões tratadas, hoje, não se esgotam pela interrogação do nosso presente, mas descendem de decisões ou opções feitas no passado, cujos reflexos podem ser vistos no momento atual. Assim, esse plano será visto, considerando-se todo o contexto histórico no qual está inserido, com foco na questão da educação infantil, mais especificamente, no ProInfancia.

Ao final deste trabalho, serão apresentados resultados decorrentes da análise do ProInfancia, no período estabelecido para a verificação de sua execução, com vistas a contribuir para novos estudos relativos ao tema. 


\section{2 - OBJETIVOS DO TRABALHO}

\section{1 - Objetivo Geral}

O objetivo geral deste trabalho consiste em analisar o ProInfancia de 2007 a outubro de 2008, como parte da política pública prevista no PDE para a educação infantil.

\section{2 - Objetivos Específicos}

$\checkmark$ Verificar a adesão de municípios e estados ao Plano de Metas Compromisso Todos pela Educação.

$\checkmark$ Verificar a execução física e financeira do ProInfancia pelo FNDE no período de 2007 a outubro de 2008.

$\checkmark$ Verificar a necessidade de ajustes no plano com relação ao ProInfancia.

$\checkmark$ Apresentar resultados que possam subsidiar novos estudos do ProInfancia. 


\section{3 - REVISÃO TEÓRICA}

Ao se examinar a evolução das políticas públicas, é preciso considerar que as análises das políticas adotadas no presente momento extrapolam os limites deste governo, posto que as diretrizes educacionais desta década, de fato, gestaram-se em anos anteriores. Desse modo, para se compreenderem as bases que ensejaram a criação do PDE, faz-se necessário conhecer as políticas educacionais adotadas nas últimas décadas, em busca da identificação das correspondentes bases ideológicas e filosóficas que as justificam.

Azevedo (2004) afirma que o conceito de políticas públicas implica considerar os recursos de poder que operam na sua definição e que têm nas instituições do Estado, sobretudo na máquina governamental, o seu principal referente. A autora enfatiza que outra importante dimensão a ter em vista nessas análises é que as políticas públicas são definidas, implementadas, reformuladas ou desativadas com base na memória da sociedade ou do estado em que têm lugar e que, por isso, guardam estreita relação com as representações sociais que cada sociedade desenvolve sobre si própria, as quais são construções informadas pelos valores, símbolos, normas, enfim, pelas representações sociais que integram o universo cultural e simbólico de uma determinada realidade. Isso significa que a análise de cada política pública adotada somente será válida se levar em conta o contexto social e histórico no qual se enquadra.

Nesse sentido, é importante identificar o espaço teórico-analítico próprio das políticas públicas, em geral, e da política educacional, em particular. Esses espaços representam a materialidade da intervenção do Estado, ou seja, o Estado em ação, resgatando, assim, as particularidades da política educacional contextualizadas segundo as distintas vertentes analíticas.

Afonso (2003), a partir de um enfoque sociológico, analisa a formulação de políticas educacionais e conclui que a redefinição do papel do Estado é condição sine qua non para a configuração dessas políticas, bem como de uma "política de transformação”. Da mesma forma, não é possível tratar de políticas educacionais, sob um foco sociológico, sem a remissão para uma teoria do Estado ou, pelo menos, para alguns pressupostos teóricoconceituais referenciáveis a uma ou mais teorias do Estado.

Abordando o tema da globalização, o autor traz à tona a questão que hoje se impõe segundo a qual, dada a desnacionalização do Estado, não teriam sentido teorias que se baseiam nos pressupostos do Estado-nação, isto é, teorias cuja capacidade explicativa supõe a existência de uma grande autonomia de decisão do poder político em uma determinada 
configuração territorial. Na verdade, o contexto atual demonstra que as teorias pluralistas, por pretenderem justificar a ação do Estado como expressão neutra de uma suposta vontade geral, assim como algumas teorias marxistas mais ortodoxas, que refletem pouco distanciamento do determinismo classista na concepção da ação do Estado, tornaram-se gradualmente incapazes de explicar a relação deste com os novos movimentos sociais, sobretudo, os que são fundados em processos contra-hegemônicos locais e mais centrados na valorização das subjetividades e identidades multiculturais e de gênero. Para o autor, mesmo as teorias neomarxistas ou outras que privilegiam a autonomia relativa do Estado parecem tender, também, a ficar relativamente anacrônicas, dada não apenas a erosão do Estado-providência como forma política do Estado capitalista democrático, mas, principalmente, por todo o trabalho de inculcação simbólica que consegue impor a inevitabilidade da globalização neoliberal e todas as suas conseqüências nos campos político, econômico, cultural e educacional.

Held (1995 apud Afonso, 2003) afirma que, em uma época em que coexistem múltiplos centros de poder e sistemas de autoridade, dentro e fora das fronteiras nacionais, é necessário renovar as bases da política e da teoria democráticas, separando-se o conceito de poder legítimo ou autoridade de sua associação tradicional com os Estados e com os limites rígidos das fronteiras nacionais. Isso não implicaria abandonar o Estado moderno, mas, sim, concebê-lo como elemento de um contexto mais amplo de condições, relações e associações políticas.

Partindo para uma contextualização histórica do papel do Estado, Azevedo (2004) afirma que o final dos anos 60 e os anos 70 assistiram a uma extensa produção teórica no campo da tradição marxista, gerando um conjunto diferenciado de interpretação e de correntes. Tendo em vista a crise econômica existente nesse período, o Estado intervinha sempre no intuito de regulamentar, surgindo, assim, a problematização, o debate e a busca do entendimento do tipo de regulação forjado pelo mundo capitalista. Nesse mesmo contexto, os postulados do liberalismo clássico, representado pelo neoliberalismo, tiveram espaço propício na crise. A partir dos anos 80, as questões da intervenção estatal e dos destinos da democracia passaram a ser tematizadas em outra direção. Buscou-se, então, o entendimento dos novos padrões de sociabilidade emergentes e soluções teórico-políticas capazes de bloquear as propostas neoconservadoras em relação aos mercados e à proteção social.

Nesse cenário, observa-se que as raízes da corrente neoliberal descendem da teoria de Estado, formulada a partir do século XVII para expressar o ideário do liberalismo clássico então emergente, a qual foi sendo paulatinamente modificada e adaptada, à medida que o 
avanço do capitalismo delineava a estrutura de classes com maior nitidez, trazendo-a para o centro da cena econômica e política.

Com base na economia política clássica, surge a concepção da “democracia utilitarista”, postulando a neutralidade do Estado. De acordo com essa teoria, caberia a este o papel de guardião dos interesses públicos. Sua função seria tão-somente responder pelo provimento de alguns bens essenciais, a exemplo da educação, da defesa e da aplicação das leis (MacPherson, 1978).

No Brasil, a educação escolar, desde a Independência, esteve ligada às políticas públicas, entendidas como forma de intervenção estatal na oferta e proteção de determinados direitos da cidadania. O Estado brasileiro apresenta-se como regulador no estabelecimento de uma política social dentro de uma concepção liberal clássica. Assim, a Constituição Federal traz como dever do Estado o oferecimento de educação pública e gratuita.

A Lei $\mathrm{n}^{\circ}$ 10.172, de 9 de janeiro de 2001, que institui o PNE, logo na sua apresentação, expõe as metas a serem alcançadas e finaliza com a seguinte afirmativa: “Os objetivos e as metas deste plano somente poderão ser alcançados se ele for concebido e acolhido como Plano de Estado, mais do que Plano de Governo e, por isso, assumido como um compromisso da sociedade para consigo mesma”. Sua aprovação pelo Congresso Nacional, em um contexto de expressiva participação social, seu acompanhamento e sua avaliação pelas instituições governamentais e da sociedade civil e a conseqüente cobrança das metas nele propostas são fatores decisivos para que a educação produza uma grande mudança no panorama do desenvolvimento, da inclusão social, da produção científica e tecnológica e da cidadania do povo brasileiro.

No que diz respeito à educação infantil, o PNE considera que essa etapa de ensino, por ser a primeira da educação básica, é a que estabelece as bases da personalidade humana, da inteligência, da vida emocional e da socialização. Ademais, certifica que, no âmbito internacional, a educação infantil terá um papel cada vez maior no que diz respeito à formação integral da pessoa, ao desenvolvimento de sua capacidade de aprendizagem e à elevação do seu nível de inteligência. Considera, portanto, que a inteligência não é herdada geneticamente nem transmitida pelo ensino, mas construída pela criança, a partir do nascimento, na interação social mediante a ação sobre os objetos, as circunstâncias e os fatos.

A educação infantil, no sentido constitucional, significando a modalidade específica das instituições educacionais para a criança de zero a seis anos de idade, segundo Kuhlmann Jr., surgiu, no Brasil, como parte de uma série de iniciativas reguladoras da vida social, na 
segunda metade do século XIX, ou seja, as creches, as escolas maternais e os jardins-deinfância, tais como os conhecemos hoje, existem no nosso país há pouco mais de um século.

\begin{abstract}
Entretanto, isso não quer dizer que se perca de vista a reflexão sobre os cinco séculos do país, pois desde o período pré-colonial brasileiro, aquela dimensão mais ampla, envolvendo as características culturais e sociais, as representações, os conhecimentos sobre a educação das crianças pequenas, deixou heranças nessa história mais recente, manifestas nas propostas, nas práticas e nas políticas educacionais (Kuhlmann Jr., 2000).
\end{abstract}

O mesmo autor afirma que as creches, os jardins-de-infância e as escolas maternais surgiram, inicialmente, em instituições vinculadas a organismos educacionais ou de assistência social ou de saúde, destinados ao atendimento de crianças pobres. Essas instituições visavam atender a necessidade premente da mulher trabalhadora que precisava deixar seus filhos pequenos para enfrentar a labuta diária pelo salário. No decorrer das décadas, tal atendimento foi se modificando de forma lenta, no sentido de se incorporar ao sistema educacional.

Partindo de reivindicações de grupos organizados da sociedade, a Constituição de 1988 estabelece que as creches e pré-escolas passariam a compor os sistemas educacionais. Essa determinação ganha estatuto legal mais definido apenas oito anos depois, com a Lei de Diretrizes e Bases da Educação (LDB) nº 9.394/96.

Ainda segundo Kuhlmann Jr. (2000), o reconhecimento dessas instituições como parte do sistema educacional apontou para a possibilidade de superação dos espaços de segregação social, que isolavam crianças pobres em instituições vinculadas aos órgãos de assistência social, e o respeito à criança tornou-se requisito para a educação infantil. No entanto, deve-se considerar que, embora tenha havido progresso, para avançar, faz-se necessário ir além da comparação linear entre realidades distintas, de modo a identificar as raízes, o processos, as dinâmicas e as tensões que envolvem o tema e perceber que há quase tudo por fazer. A presença de grupos organizados da sociedade é um elemento fundamental para as conquistas obtidas e para alargar o posicionamento crítico. Portanto, é mister repensar a educação infantil, considerando-se o número de crianças que se precisa alcançar e superando-se dificuldades quanto a indefinições no que diz respeito às políticas, à regulamentação, aos orçamentos e a outros indicadores.

Barreto (2003), em seu estudo denominado “A educação infantil no contexto das políticas públicas”, faz um apanhado das políticas e programas do governo federal, na segunda gestão do governo Fernando Henrique Cardoso, dirigidos a crianças de zero a seis 
anos de idade, analisando, paralelamente, alguns desafios impostos pelo PNE no que se refere à educação infantil. Nesse trabalho, a autora destaca que grandes foram os avanços no atendimento a esse segmento, no âmbito jurídico e na gestão governamental dos recursos, frisando, inclusive, a ampliação da participação da sociedade, especialmente, no controle social das ações dos governos. Entretanto, conclui que ainda há muito a fazer para garantir à criança pequena um desenvolvimento integral adequado, sendo uma evidência desse fato a necessidade da participação da União, de modo mais efetivo, na implementação de políticas públicas, inclusive em cumprimento aos objetivos estabelecidos no PNE. 


\section{4 - METODOLOGIA}

Segundo Gil (2002), quanto aos objetivos, uma pesquisa pode ser classificada em: descritiva, explicativa e exploratória. Neste trabalho, a pesquisa se configura como descritiva e explicativa, na medida em que busca descrever as características de determinado fenômeno - o PDE, no caso -, ou estabelecer relações entre variáveis. Como se trata de um estudo de caso, cujo foco é um programa no âmbito do PDE, o ProInfancia, a pesquisa enquadra-se, também, na perspectiva qualitativa. Dessa forma, este trabalho foi concebido a partir da seguinte sistematização: coleta de dados secundários por meio de pesquisa documental nas páginas institucionais da Internet e documentação sobre o PDE e o ProInfancia, como também coleta de dados primários, por meio de entrevistas semi-estruturadas realizadas com: o Coordenador-Geral da então Coordenação-Geral de Análise de Projetos (CGAAP) (2007), atual Coordenação-Geral de Infra-Estrutura Educacional (CGEST), área responsável pela operacionalização do ProInfancia, no FNDE; com um engenheiro da área e com um representante de município beneficiado pelo programa.

Além disso, utilizaram-se os bancos de dados dos sistemas informatizados do FNDE e do MEC para a pesquisa documental. Após a coleta, realizou-se a análise dos dados, o que subsidiou os resultados para a conclusão do trabalho.

Considerando-se que este estudo remonta ao atendimento dado às ações do MEC, por transferência voluntária, geridas pelo FNDE, faz-se necessário entender como era o processo anterior à nova proposta do PDE. 


\section{5 - CARACTERIZAÇÃO DO MARCO REGULATÓRIO}

\section{1 - O Plano de Desenvolvimento da Educação (PDE)}

\subsection{1 - A proposta do Plano de Aceleração do Crescimento (PAC)}

O governo brasileiro iniciou, em 2003, a implantação de um novo modelo de desenvolvimento econômico e social, o qual procura combinar crescimento da economia com distribuição de renda e proporcionar a diminuição da pobreza e a inclusão de milhões de brasileiros no mercado formal de trabalho.

Um dos pilares do Programa de Aceleração do Crescimento (PAC) é a desoneração de tributos para incentivar mais investimentos no Brasil. Por seu intermédio, está prevista, entre outras ações, a redução de tributos para os setores de semicondutores, de equipamentos aplicados à TV digital, de microcomputadores, de insumos e serviços usados em obras de infra-estrutura e de perfis de aço. O plano contempla, também, medidas fiscais de longo prazo, como é caso do controle das despesas com a folha de pagamento e a modernização do processo de licitação, fundamentais para garantir o equilíbrio dos gastos públicos.

As medidas econômicas para o crescimento do País abrangem: Estímulo ao Crédito e ao Financiamento, Melhoria do Ambiente de Investimento, Desoneração e Administração Tributária, Medidas Fiscais de Longo Prazo e Consistência Fiscal e Medidas Institucionais. Entre as medidas adotadas para a promoção de melhorias na área social, no âmbito do MEC, está o PDE.

Segundo palavras do próprio presidente da República,

O PAC combina um conjunto expressivo de investimentos em infra-estrutura com desonerações tributárias e melhorias institucionais no ambiente de negócios, e transforma o País em um verdadeiro canteiro de obras que vão da logística de transporte ao saneamento e habitação. Ao colocar o aumento do investimento em infra-estrutura como prioridade da política econômica, o PAC representou uma mudança na agenda dessa política*.

O PAC prevê investimentos de 503,9 bilhões de reais até 2010, divididos em três eixos: logística (58,3 bilhões), energia (274,8 bilhões) e social e urbano (170,8 bilhões). No âmbito de cada ministério foram implementadas as ações do PAC, sendo o PDE o chamado

\footnotetext{
* Discurso pronunciado pelo presidente Luís Inácio Lula da Silva na Bolsa de Valores de São Paulo (BVSP) em 16 de junho de 2008.
} 
PAC da Educação. Para a compreensão das mudanças introduzidas pelo PDE, julga-se oportuno descrever a forma adotada pelo MEC para o repasse dos seus recursos, por meio de convênios.

\subsection{2 - O modelo anterior de atendimento às transferências voluntárias}

Entende-se por transferência voluntária o repasse de recursos financeiros pela União aos estados, ao Distrito Federal, aos municípios, a instituições sem fins lucrativos e a órgãos federais em decorrência da celebração de convênios, acordos, ajustes ou outros instrumentos similares, cuja finalidade é a realização de obras e/ou serviços de interesse comum e coincidente às três esferas do governo.

A execução das ações orçamentárias por transferências voluntárias, no âmbito do MEC e do FNDE com celebração de convênios, até 2006, era implementada a partir das seguintes etapas e procedimentos:

a) mediante reuniões entre as secretarias-fim do MEC e o FNDE, definiam-se quais ações orçamentárias iriam ser financiadas suplementarmente às ações educacionais preestabelecidas por secretaria do MEC, individualmente;

b) essas ações eram executadas após a publicação de resoluções emitidas pelo Conselho Deliberativo do FNDE, as quais estabeleciam critérios e requisitos legais para o atendimento;

c) por meio das resoluções, as entidades tomavam conhecimento de todos os documentos e prazos legais para se habilitarem e se cadastrarem com vistas à celebração de convênios com o FNDE e o MEC, naquele exercício;

d) os municípios e as demais entidades pleiteantes, ao tomarem conhecimento das resoluções publicadas e disponibilizadas no sítio do FNDE, encaminhavam à autarquia os planos de trabalho preenchidos conforme critérios de cada resolução, com os documentos referentes à habilitação legal para participar;

e) os referidos documentos de habilitação e os planos de trabalho, após serem recebidos pelo FNDE, eram protocolados e cadastrados, dando origem aos Planos de Trabalho Anuais (PTAs), os quais eram enviados a cada secretaria-fim responsável pela análise e deliberação quanto ao mérito do atendimento; 
f) cada secretaria-fim do MEC (Secretaria de Educação Básica - SEB; Secretaria de Educação Continuada, Alfabetização e Diversidade - SECAD; e Secretaria de Educação Especial - Seesp), por exemplo, analisava os PTAs, enfocando a capacidade legal do pleiteante em promover a educação e a real necessidade da clientela a ser beneficiada. Consideravam-se como parâmetros, entre outros, os dados informados no censo escolar do ano anterior;

g) após a análise, o processo retornava ao FNDE que, por sua vez, verificava a regularidade fiscal da entidade e sua situação de adimplência com a União, e procedia à celebração dos convênios após confirmada a disponibilidade financeira para o atendimento;

h) prosseguindo à celebração do convênio, eram colhidas as assinaturas e publicado o seu extrato no Diário Oficial da União (DOU), visando dar publicidade ao ato. Em seguida, era efetuado o crédito na conta do convênio.

Em seção posterior deste trabalho se verificará como esses procedimentos foram alterados, com exceção dos constantes nas letras “g” e “h”, tendo-se em vista o novo modelo de atendimento promovido pela proposta do PDE, a partir de 2007.

$\mathrm{O}$ atendimento nos moldes acima, entre outras coisas, possibilitava a qualquer beneficiário solicitar recursos, a despeito da sua real necessidade, desde que se enquadrasse nos critérios postos. Dessa forma, não se fazia um estudo anterior das necessidades daqueles que solicitavam recursos, sendo que vários municípios carentes deixavam de ser atendidos por entraves burocráticos. O ministério carecia de uma postura proativa no sentido de adequar o atendimento aos proponentes mais necessitados.

Esse tipo de atendimento representou, na realidade, um vil processo histórico imposto pela burocracia, que dava margem à intermediação de lobistas e escritórios que cobravam, de forma ilícita, percentuais dos recursos repassados aos municípios pelos convênios, tendo em vista sua intermediação.

\subsection{3 - A proposta do Plano de Desenvolvimento da Educação (PDE)}

Formar indivíduos capazes de assumir uma postura crítica e criativa perante o mundo é o objetivo da educação que inspira o PDE, conforme exposto na publicação “O Plano de Desenvolvimento da Educação: razões, princípios e programas”, lançada pelo MEC em 2008. Essa visão, que perpassa a execução de vários programas do ministério, reconhece na 
educação uma face do processo dialético que se estabelece entre socialização e individuação da pessoa e que visa a construção da autonomia do cidadão.

Nesse contexto, a educação formal pública é a cota de responsabilidade do Estado em um esforço social conjunto mais abrangente, o qual transcende a escola e perpassa os demais segmentos sociais, como a família, a comunidade e toda forma de interação na qual os indivíduos tomam parte, especialmente no trabalho.

Os preceitos constitucionais como: a construção de uma sociedade livre, justa e solidária; a garantia do desenvolvimento nacional; a erradicação da pobreza e da marginalização; a redução das desigualdades sociais e regionais; e a promoção do bem de todos, sem preconceitos de origem, raça, sexo, cor, idade e quaisquer outras formas de discriminação, estão em harmonia com os objetivos fundamentais republicanos, expressos nos programas que compõem o plano. A educação, portanto, é aí concebida como eixo estruturante da ação do Estado, pautada na construção da autonomia, na inclusão social e no respeito à diversidade, buscando garantir o desenvolvimento nacional.

Sob a ótica do plano, a educação deve promover a redução das desigualdades sociais e regionais, o que se traduz em equalização das oportunidades de acesso à educação de qualidade.

Considerando-se a concepção de educação alinhada aos preceitos constitucionais, fazse mister, a partir dessa visão, a construção de uma unidade dos sistemas educacionais do País como sistema nacional pressupondo multiplicidade, não uniformidade. Logo, exige-se também pensar etapas, modalidades e níveis educacionais não apenas na sua unidade, mas considerando-se indissociáveis a educação e a ordenação do territorial, tendo-se em vista ser o território o espaço onde se constata a ocorrência dos fatos culturais e sociais proporcionados dentro de um espaço e um tempo determinados. Assim, considera-se ser o desenvolvimento econômico e social a única forma de garantir a todos e a cada um o direito de aprender até onde o permitam suas aptidões e vontade.

Outra argumentação básica é a de que a relação recíproca entre educação e desenvolvimento só se fixa quando as ações do Estado são alinhadas e os nexos entre elas são fortalecidos, potencializando seus efeitos mútuos. Desse movimento de busca de sintonia das políticas públicas entre si depende a potencialidade dos planos setoriais, inclusive o educacional, que passam, nesses termos, à condição de exigência do desenvolvimento econômico e social, garantindo-se que o todo seja maior que a soma das partes.

O PDE, nesse sentido, pretende concretizar as metas propostas no PNE, sendo mais do que a tradução instrumental do mesmo, buscando transcendê-lo no que concerne à questão da 
melhoria da qualidade da educação. O PDE, portanto, se apresenta como plano executivo, como conjunto de programas que visam dar conseqüência às metas quantitativas estabelecidas no PNE; porém, a partir dos enlaces conceituais propostos, evidencia-se que não se trata, quanto à qualidade, de uma execução marcada pela neutralidade, pois o PDE está ancorado, de um lado, em uma concepção substantiva de educação que perpassa todos os níveis e modalidades educacionais e, de outro, em fundamentos e princípios voltados para a consecução dos objetivos republicanos presentes na Constituição, sobretudo, no que concerne ao que se designa por visão sistêmica da educação e à sua relação com a ordenação territorial e o desenvolvimento econômico e social.

A partir dessas considerações, passa-se a descrever tópicos que identificam a visão política do plano, bem como suas bases filosóficas conforme colocadas nos documentos oficiais que o norteiam.

\subsection{4 - A visão sistêmica em oposição à gerencialista}

O PDE propõe uma visão da educação diferenciada da que predominou no país até recentemente. Historicamente, a educação brasileira era considerada a partir de uma visão gerencialista, fiscalista, fragmentada - em que níveis, etapas e modalidades não eram vistos como parte de um processo -, a qual perdurou por um longo período e tomava os investimentos em educação como gastos, em um suposto contexto de restrição fiscal.

Em conseqüência, esse período caracterizou-se por criar um conjunto de falsas oposições, que prejudicaram enormemente o desenvolvimento da educação no país. A mais indesejável de tais oposições é a que havia entre educação básica e educação superior. Diante da falta de recursos, alegava-se que caberia ao gestor público optar pela primeira, sem que a União aumentasse o investimento na educação básica. Dessa forma, a educação superior ficou prejudicada por um longo período, visto que o custeio para esse nível de ensino foi reduzido em $50 \%$ em dez anos, o que inviabilizou a expansão significativa da rede. Tudo isso devido à revogação, em 1996, do parágrafo único do artigo 60 do Ato das Disposições Constitucionais Transitórias, no qual se estabelecia que, nos dez primeiros anos da promulgação da Constituição, as universidades públicas descentralizariam suas atividades, de modo a estender suas unidades de ensino superior às cidades de maior densidade populacional. Essa determinação teve como conseqüência a falta de professores com licenciatura para exercer o magistério e alunos do ensino médio desmotivados pela insuficiência de oferta de ensino gratuito nas universidades públicas. 
A segunda oposição, não menos prejudicial que a primeira, estabelecia-se no nível da educação básica, formada pela educação infantil e os ensinos fundamental e médio. Derivouse da atenção quase exclusiva ao ensino fundamental, que resultou em certo descaso com as outras duas etapas e prejudicou o que supostamente se pretendia proteger. Sem que se tivesse ampliado significativamente a já alta taxa de atendimento do ensino fundamental, verificou-se uma queda no desempenho médio dos alunos dessa etapa. Desconsiderava-se o fato de que a educação infantil e o ensino médio fossem sustentáculos do ensino fundamental e que este, sem eles, não teria como avançar. Todos os estudos recentes sobre educação demonstram, inequivocamente, que a aprendizagem e o desenvolvimento dos educandos no ensino fundamental, principalmente dos alunos das classes menos privilegiadas, dependem do acesso à educação infantil.

A terceira oposição estabeleceu-se entre o ensino médio e a educação profissional, quando, nos anos 90, foi banida por decreto a previsão de oferta de ensino médio articulada à educação profissional e proibida por lei a expansão da rede federal de educação profissional e tecnológica. Nos termos legais, a expansão da oferta de educação profissional somente poderia ocorrer mediante a criação de novas unidades de ensino por parte da União e em parceria com estados, municípios, o Distrito Federal, setor produtivo ou organizações nãogovernamentais, que seriam responsáveis pela manutenção e gestão dos estabelecimentos de ensino. Nesses moldes, a União poderia construir novos estabelecimentos, desde que o custeio deles e o de pessoal fossem de responsabilidade de estados, municípios ou instituições privadas. O Congresso Nacional inseriu no projeto um dispositivo que relativizava a regra geral, excepcionando as unidades de ensino da União com obras já concluídas. O dispositivo foi vetado. Com isso, as experiências mais virtuosas de articulação do ensino médio com a educação profissional, desenvolvidas na rede federal, foram desprestigiadas.

Uma quarta oposição caracteriza-se pela dissociação entre a alfabetização e a educação de jovens e adultos (EJA), fato que se comprova quando se observa que as ações de alfabetização, de responsabilidade da União, nunca estiveram sob a alçada do MEC e jamais foram articuladas com a EJA. Várias foram as campanhas realizadas, porém, jamais como programas estruturados de educação continuada em colaboração com os sistemas educacionais. Em conseqüência, perdia-se de vista a elevada dívida educacional com grupos sociais historicamente fragilizados. Assim, a exclusão da EJA do Fundo de Manutenção e Desenvolvimento do Ensino Fundamental e de Valorização do Magistério (Fundef) foi simbólica: significou o repúdio, por parte do Estado, da dívida social com aqueles que não 
exerceram a tempo, por razões inteiramente alheias a sua vontade, seu direito de aprender direito adquirido tomado por direito alienado.

A quinta e última oposição a ser combatida, na ótica do PDE, é a visão fracionada entre a educação regular e a educação especial. Contrariando a concepção sistêmica da transversalidade da educação especial nos diferentes níveis, etapas e modalidades de ensino, a educação não se estruturou na perspectiva da inclusão e do atendimento às necessidades educacionais especiais, limitando o cumprimento do princípio constitucional que prevê a igualdade de condições para o acesso e a permanência na escola e a continuidade nos níveis mais elevados de ensino.

O PDE procura, portanto, superar essas falsas oposições por meio de uma visão sistêmica da educação. Dessa forma, destaca a educação como um processo de socialização e individuação voltado para a autonomia e preconiza que, como processo, não pode ser artificialmente segmentada, devendo ser tratada como unidade da creche à pós-graduação, ampliando o horizonte educacional de todos e de cada um, independentemente do estágio em que se encontrem no ciclo educacional.

A visão sistêmica da educação implica não apenas compreender o ciclo educacional de modo integral, como também promover a articulação entre as políticas especificamente orientadas a cada nível, etapa ou modalidade, bem como efetuar a coordenação entre os instrumentos de política pública disponíveis. Significa, então, reconhecer as conexões intrínsecas entre educação básica, educação superior, educação tecnológica e alfabetização e, a partir dessas conexões, potencializar as políticas de educação de forma a que se reforcem reciprocamente.

Outro fator imprescindível para o PDE é o regime de colaboração entre a União, os estados, o Distrito Federal e os municípios em matéria educacional, caracterizando-se este como o compartilhamento de competências políticas, técnicas e financeiras para a execução de programas de manutenção e desenvolvimento da educação, de forma a combinar a atuação dos entes federados sem lhes ferir a autonomia. É propósito do plano que se efetive a articulação dessa divisão de tarefas em grandes eixos (educação básica, superior, profissional e continuada) com regras transparentes e metas precisas, passíveis de acompanhamento público e de controle social.

A União, em consonância com o mandamento constitucional, irá exercer, “em matéria educacional, função redistributiva e supletiva, de forma a garantir equalização de oportunidades educacionais e padrão mínimo de qualidade do ensino mediante assistência técnica e financeira aos estados, ao Distrito Federal e aos municípios”. Conseqüentemente, a 
partir do PDE, a União passa a assumir maiores compromissos, inclusive financeiros, e coloca à disposição dos entes federados instrumentos eficazes de avaliação e de implementação de políticas de melhoria da qualidade da educação, sobretudo, da educação básica pública.

Dois outros imperativos se desdobram dos propósitos do plano: responsabilização (accountability), especialmente, da classe política e mobilização social em torno da questão da educação, possibilitando à sociedade acompanhar sua execução, propor ajustes e fiscalizar o cumprimento dos deveres do Estado.

Em resumo, o PDE sustenta-se em seis pilares: visão sistêmica da educação, territorialidade, desenvolvimento, regime de colaboração, responsabilização e mobilização social, os quais se configuram como desdobramentos conseqüentes de princípios e objetivos constitucionais, com a finalidade de expressar a união necessária entre educação, território e desenvolvimento, de um lado, e entre qualidade, eqüidade e potencialidade, de outro. Além disso, busca, a partir de uma perspectiva sistêmica, dar conseqüência, em regime de colaboração, às normas gerais da educação na articulação com o desenvolvimento socioeconômico que se realiza no território, ordenado segundo a lógica do arranjo educativo local, regional ou nacional.

Vale, ainda, enfatizar que seus programas se organizam em torno de quatro eixos norteadores: educação básica, educação superior, educação profissional e alfabetização. Compreende mais de 40 programas, dentre os quais se encontra o ProInfancia, o qual se destaca como o foco deste trabalho e cujo detalhamento se dará em seção posterior.

Por fim, cumpre informar que o conjunto de ações do PDE, visando ao ensino básico (educação infantil, ensino fundamental e ensino médio), foi resumido no Plano de Metas Compromisso Todos pela Educação, do qual se passa a tratar.

\subsection{5 - O Plano de Metas Compromisso Todos pela Educação}

O Plano de Metas Compromisso Todos pela Educação, instituído pelo Decreto $n^{\circ}$ 6.094, de 24 de abril de 2007, caracteriza-se pela conjugação dos esforços da União, dos estados, do Distrito Federal e dos municípios, atuando em regime de colaboração, das famílias e da comunidade, em proveito da melhoria da qualidade da educação básica. É o que se pode chamar de base para a construção de uma educação na visão do PDE.

A participação da União no Plano de Metas pauta-se pela realização direta ou pelo incentivo e apoio à implementação, por municípios, pelo Distrito Federal, pelos estados e 
respectivos sistemas de ensino, das 28 diretrizes que norteiam a adesão ao referido plano, que são:

I. Estabelecer como foco a aprendizagem, apontando resultados concretos a atingir;

II. Alfabetizar as crianças até, no máximo, os oito anos de idade, aferindo os resultados por exame periódico específico;

III. Acompanhar cada aluno da rede individualmente, mediante registro da sua freqüência e do seu desempenho em avaliações, as quais devem ser realizadas periodicamente;

IV. Combater a repetência, dadas as especificidades de cada rede, pela adoção de práticas como aulas de reforço no contraturno, estudos de recuperação e progressão parcial;

V. Combater a evasão pelo acompanhamento individual das razões da não-freqüência do educando e sua superação;

VI. Matricular o aluno na escola mais próxima da sua residência;

VII. Ampliar as possibilidades de permanência do educando sob a responsabilidade da escola para além da jornada regular;

VIII. Valorizar a formação ética, artística e a educação física;

IX. Garantir o acesso e a permanência das pessoas com necessidades educacionais especiais nas classes comuns do ensino regular, fortalecendo a inclusão educacional nas escolas públicas;

X. Promover a educação infantil;

XI. Manter programa de alfabetização de jovens e adultos;

XII. Instituir programa próprio ou em regime de colaboração para formação inicial e continuada de profissionais da educação;

XIII. Implantar plano de carreira, cargos e salários para os profissionais da educação, privilegiando o mérito, a formação e a avaliação do desempenho;

XIV. Valorizar o mérito do trabalhador da educação, representado pelo desempenho eficiente no trabalho, pela dedicação, pela assiduidade, pela pontualidade, pela responsabilidade, pela realização de projetos e trabalhos especializados, pelos cursos de atualização e desenvolvimento profissional;

XV. Dar conseqüência ao período probatório, tornando o professor efetivo estável após avaliação, preferencialmente, externa ao sistema educacional local;

XVI. Envolver todos os professores na discussão e elaboração do projeto políticopedagógico, respeitadas as especificidades de cada escola;

XVII. Incorporar ao núcleo gestor da escola coordenadores pedagógicos que acompanhem as dificuldades enfrentadas pelo professor; 
XVIII. Fixar regras claras, considerando mérito e desempenho, para nomeação e exoneração de diretor de escola;

XIX. Divulgar na escola e na comunidade os dados relativos à área da educação, com ênfase no Índice de Desenvolvimento da Educação Básica (Ideb);

XX. Acompanhar e avaliar, com participação da comunidade e do Conselho de Educação, as políticas públicas na área de educação e garantir condições, sobretudo institucionais, de continuidade das ações efetivas, preservando a memória daquelas realizadas;

XXI. Zelar pela transparência da gestão pública na área da educação, garantindo o funcionamento efetivo, autônomo e articulado dos conselhos de controle social;

XXII. Promover a gestão participativa na rede de ensino;

XXIII. Elaborar plano de educação e instalar Conselho de Educação, quando inexistentes;

XXIV. Integrar os programas da área da educação com os de outras áreas, como saúde, esporte, assistência social, cultura, entre outras, com vista ao fortalecimento da identidade do educando com sua escola;

XXV. Fomentar e apoiar os conselhos escolares, envolvendo as famílias dos educandos, com as atribuições, entre outras, de zelar pela manutenção da escola e pelo monitoramento das ações, bem como pela consecução das metas do compromisso;

XXVI. Transformar a escola em um espaço comunitário e manter ou recuperar espaços e equipamentos públicos da cidade que possam ser utilizados pela comunidade escolar;

XXVII. Firmar parcerias externas à comunidade escolar, visando à melhoria da infra-estrutura da escola ou à promoção de projetos socioculturais e ações educativas;

XXVIII. Organizar um comitê local do compromisso, com representantes das associações de empresários, trabalhadores, sociedade civil, Ministério Público, Conselho Tutelar e dirigentes do sistema educacional público, encarregado da mobilização da sociedade e do acompanhamento das metas de evolução do Ideb.

A adesão voluntária de cada ente federativo ao compromisso implica a elevação da responsabilidade de promover a melhoria da qualidade da educação básica em sua esfera de competência, expressa pelo cumprimento de meta de evolução do Ideb, observando-se as 28 diretrizes propostas.

Coube ao MEC enviar aos entes que aderiram ao compromisso sua respectiva Base de Dados Educacionais, acompanhada de informe elaborado pelo Instituto Nacional de Estudos e 
Pesquisas Educacionais Anísio Teixeira (Inep), com indicação de meta a atingir e respectiva evolução no tempo, como também atestar o cumprimento dessas metas.

O município que, de alguma forma, não preencheu as condições técnicas para realização da Prova Brasil passou a ser objeto de um programa especial de estabelecimento e monitoramento das metas.

Tendo-se em vista a necessidade de formulação de estratégias de mobilização social pela melhoria da qualidade da educação básica, que subsidiarão a atuação dos agentes públicos e privados, foi instituído o Comitê Nacional Compromisso Todos pela Educação, presidido pelo ministro da Educação.

Segundo o decreto que instituiu o plano, podem colaborar com o compromisso, em caráter voluntário, outros entes públicos e privados, tais como organizações sindicais e da sociedade civil, fundações, entidades de classe empresariais, igrejas e entidades confessionais, famílias, pessoas físicas e jurídicas que se mobilizem para a melhoria da qualidade da educação básica.

\subsection{6 - O Plano de Ações Articuladas (PAR)}

O atendimento aos municípios no que concerne às transferências voluntárias ocorre mediante a assinatura de convênios, sendo condição obrigatória a formalização das ações mediante o Plano de Ações Articuladas (PAR) que se configura como o conjunto das ações a serem desenvolvidas no âmbito do PDE para cada município.

No intuito de viabilizar esse atendimento, o art. $8^{\circ}$ do Decreto $n^{0}$ 6.094/2007 expõe a forma como se dará o atendimento aos municípios, mediante ações de assistência técnica ou financeira, que privilegiarão a implementação das diretrizes constantes do art. $2^{\underline{0}}$, observados os limites orçamentários e operacionais da União.

Nos critérios de priorização do atendimento, pela União, inclui-se o Ideb, as possibilidades de incremento desse índice e a capacidade financeira e técnica do ente apoiado, na forma de normas expedidas pelo FNDE.

O MEC oferecerá seu apoio orientado a partir dos seguintes eixos de ação expressos nos programas educacionais do Plano Plurianual da União (PPA):

I. Gestão educacional;

II. Formação de professores e profissionais de serviços e apoio escolar;

III. Recursos pedagógicos;

IV. Infra-estrutura física. 
Portanto, o PAR é o conjunto articulado de ações, apoiado técnica ou financeiramente pelo MEC, que visa ao cumprimento das metas do compromisso e à observância das suas diretrizes.

Observa-se que o atendimento nos moldes do PDE traz uma grande novidade com relação ao anterior, com a formação de uma equipe técnica para prestar assistência na elaboração do diagnóstico da educação básica do sistema local. Mediante esse diagnóstico, o ente pode elaborar o PAR com auxílio dessa equipe técnica, que identificará as medidas mais apropriadas para a gestão do sistema, com vistas à melhoria da qualidade da educação básica.

O PAR é a base para o termo de convênio ou de cooperação firmado entre o MEC e o ente apoiado. Como requisito para a celebração do convênio ou termo de cooperação, há necessidade da formalização de termo de adesão, nos moldes do art. $5^{0}$ do referido decreto, e o compromisso de realização da Prova Brasil.

Cabe ao MEC a responsabilidade pelo acompanhamento geral dos planos e a cada convenente a divulgação da evolução dos dados educacionais no âmbito local.

\subsection{7 - O Índice de Desenvolvimento da Educação Básica (Ideb)}

A criação do Índice de Desenvolvimento da Educação Básica (Ideb), no contexto do PDE, visa a contribuir para a promoção de uma profunda alteração na avaliação da educação básica, na medida em que possibilita o estabelecimento de conexões entre avaliação, financiamento e gestão, invocando um conceito ainda ausente do nosso sistema educacional: a responsabilização e, como decorrência, a mobilização social.

O Ideb nasceu da preocupação de se combinarem os resultados de desempenho escolar (Prova Brasil) e os resultados de rendimento escolar (fluxo apurado pelo censo escolar) em um único indicador de qualidade, o que gerou uma nova sistemática de avaliação, exigindo uma alteração significativa na forma de se realizar o censo escolar, o qual, a partir daí, não poderia mais ser feito por escola, mas por aluno. Essa mudança permite que os dados de fluxo não mais sejam estimados por modelos matemáticos, mas baseados em dados individualizados sobre promoção, reprovação e evasão de cada estudante, diferentemente do Saeb, que era apenas um exame aplicado a cada dois anos a uma amostra de alunos de cada estado, acompanhado de um questionário, utilizado até 2005, e que apresentava limitações que se pretende superar com o novo modelo. 
Expresso em uma escala de zero a dez, o Ideb foi criado com base no Programa Educacenso, um banco de dados online com mais de 50 milhões de registros, estimado em um fluxo real, aluno por aluno, atrelado com a Prova Brasil.

Partindo desse novo indicador, o PDE procura superar algumas dificuldades do PNE em torno da questão da qualidade. A partir da criação do índice, calculado por escola, por rede e para o próprio País, foi possível fixar metas de desenvolvimento educacional de médio prazo para cada uma dessas instâncias, com metas intermediárias de curto prazo que possibilitam visualização e acompanhamento da reforma qualitativa dos sistemas educacionais.

O Ideb calculado para o País, relativo aos anos iniciais do ensino fundamental, foi de 3,8, contra uma média estimada de 6 dos países desenvolvidos, que passa a ser a meta nacional para 2022. Pretende-se alcançar o nível médio de desenvolvimento da educação básica dos países integrantes da Organização para a Cooperação Econômica e o Desenvolvimento (OCDE), no ano em que o Brasil irá comemorar dois séculos de sua Independência.

Cabe enfatizar a enorme dispersão do Ideb entre escolas e redes. Foram encontrados, nas redes, índices que variam de 1 a 6,8. Nas escolas, a variação é ainda maior: de 0,7 a 8,5, o que evidencia a necessidade de se promover a vinculação entre educação, ordenação do território e desenvolvimento econômico e social, conforme proposta do PDE.

Faz-se necessário considerar que, em cada estado e em cada município, é forte a correlação entre o Ideb das redes municipais e o Ideb da rede estadual, o que exige atenção às redes no seu conjunto. Vale notar, contudo, que a forte correlação observada não anula o fato de que, na maioria dos casos, o Ideb da rede estadual, em cada município, é superior ao Ideb da rede municipal. Isso sugere que a municipalização ainda deixa muito a desejar.

A pesquisa realizada para a implementação do Ideb, com relação às transferências voluntárias da União, demonstrou que os municípios mais necessitados do apoio técnico e financeiro são os que menos recursos receberam, até hoje. Nesse sentido, o Ideb permite identificar as redes e as escolas públicas mais frágeis a partir de critérios objetivos e obriga a União a dar respostas imediatas para os casos mais dramáticos, ao organizar o repasse de transferências voluntárias com base em critérios substantivos.

A seguir, apresenta-se o Quadro 1, de resultados e metas para o Ideb em 2005. 
QUADRO 1 - Resultados e metas para o Ideb em 2005 e projeções para o Brasil

\begin{tabular}{|c|c|c|c|c|c|c|c|c|c|c|c|c|}
\hline & \multicolumn{4}{|c|}{$\begin{array}{l}\text { Anos Iniciais do Ensino } \\
\text { Fundamental }\end{array}$} & \multicolumn{4}{|c|}{$\begin{array}{c}\text { Anos Finais do Ensino } \\
\text { Fundamental }\end{array}$} & \multicolumn{4}{|c|}{ Ensino Médio } \\
\hline & \multicolumn{2}{|c|}{$\begin{array}{c}\text { Ideb } \\
\text { observado }\end{array}$} & \multicolumn{2}{|c|}{ Metas } & \multicolumn{2}{|c|}{$\begin{array}{c}\text { Ideb } \\
\text { observado }\end{array}$} & \multicolumn{2}{|c|}{ Metas } & \multicolumn{2}{|c|}{$\begin{array}{c}\text { Ideb } \\
\text { observado }\end{array}$} & \multicolumn{2}{|c|}{ Metas } \\
\hline & 2005 & 2007 & 2007 & 2021 & 2005 & 2007 & 2007 & 2021 & 2005 & 2007 & 2007 & 2021 \\
\hline TOTAL & 3,8 & 4,2 & 3,9 & 6,0 & 3,5 & 3,8 & 3,5 & 5,5 & 3,4 & 3,5 & 3,4 & 5,2 \\
\hline \multicolumn{13}{|c|}{ Dependência Administrativa } \\
\hline Pública & 3,6 & 4,0 & 3,6 & 5,8 & 3,2 & 3,5 & 3,3 & 5,2 & 3,1 & 3,2 & 3,1 & 4,9 \\
\hline Federal & 6,4 & 6,2 & 6,4 & 7,8 & 6,3 & 6,1 & 6,3 & 7,6 & 5,6 & 5,7 & 5,6 & 7,0 \\
\hline Estadual & 3,9 & 4,3 & 4,0 & 6,1 & 3,3 & 3,6 & 3,3 & 5,3 & 3,0 & 3,2 & 3,1 & 4,9 \\
\hline Municipal & 3,4 & 4,0 & 3,5 & 5,7 & 3,1 & 3,4 & 3,1 & 5,1 & 2,9 & 3,2 & 3,0 & 4,8 \\
\hline Privada & 5,9 & 6,0 & 6,0 & 7,5 & 5,8 & 5,8 & 5,8 & 7,3 & 5,6 & 5,6 & 5,6 & 7,0 \\
\hline
\end{tabular}

Fonte: Saeb e Censo Escolar. Retirado do sítio do MEC/FNDE.

\subsection{8 - O novo modelo de atendimento às transferências voluntárias}

O escopo desse novo modelo, a partir de 2007, é atender imediatamente os 1.242 municípios e as 7.085 escolas com os mais baixos indicadores e, a curto prazo, todos os que estiverem abaixo da média nacional. Isso demandou do MEC uma mudança radical de postura no atendimento aos entes federados. Em vez de aguardar as respostas às suas resoluções, selecionando os “melhores" projetos apresentados, muitas vezes confeccionados por consultorias contratadas, agora se vai ao encontro de quem mais precisa, construindo o regime de colaboração na prática, ou seja, os repasses não mais ocorrem com base em critérios subjetivos.

Esse modelo de atendimento vem ao encontro de uma necessidade antiga do MEC de conhecer seus parceiros indo à ponta. Assim, o relacionamento entre governos, mediado pelo tráfico de influência, pela pressão político-partidária ou pelo vaivém de interesses, pretende dar lugar ao relacionamento entre Estado nacional e os entes federados, mediado pelo direito de aprender do educando. 


\section{2 - O Programa Nacional de Reestruturação e Aparelhagem da Rede Escolar Pública de Educação Infantil (ProInfancia)}

O Programa Nacional de Reestruturação e Aparelhagem da Rede Escolar Pública de Educação Infantil (ProInfancia) foi criado por se considerarem indispensáveis a construção de creches e escolas de educação infantil e a reestruturação e aquisição de equipamentos para a rede física escolar desse nível educacional, viabilizando-se, dessa forma, a melhoria da qualidade da educação.

O programa foi instituído pela Resolução/CD/FNDE nº 6, de 24 de abril de 2007, tendo como principal objetivo prestar assistência financeira, em caráter suplementar, ao Distrito Federal e aos municípios que firmarem o Termo de Adesão ao Plano de Metas Compromisso Todos pela Educação.

Priorizou-se a construção e a reforma de escolas, visando promover a acessibilidade aos portadores de necessidades especiais, fazendo as adequações cabíveis, criando e sinalizando rotas acessíveis, ligando os ambientes de uso pedagógico, administrativo, recreativo, esportivo e de alimentação (salas de aula, fraldários, bibliotecas, salas de leitura, salas de informática, sanitários, recreio coberto, refeitório, secretaria, etc.).

Com o objetivo não só de dar acesso aos alunos portadores de necessidades especiais, mas também de incluí-los no ambiente escolar, este programa financia a construção de rampas, a colocação de corrimãos, a adequação de sanitários e outras ações cabíveis, nas escolas, sempre de acordo com as orientações da Associação Brasileira de Normas Técnicas (ABNT NBR 9050).

O orçamento do programa, em 2007, foi de 337,5 milhões de reais, conforme o Relatório de Atividades do FNDE relativo ao exercício.

Ao município interessado em ser beneficiário do ProInfancia cabe aderir ao Termo de Compromisso Todos pela Educação, do governo federal, inscrevendo-se no programa disponível na Internet, na página do FNDE e encaminhando ao órgão os documentos pertinentes, bem como elaborar o PAR.

Para a ação de construção, adotou-se o projeto-padrão, sendo que as diretrizes de implantação são definidas pelo FNDE, fazendo-se necessária a apresentação, além da documentação supracitada, dos seguintes itens: 
a) Disponibilidade de terreno com dimensões mínimas de 40m x 70m em área urbana do município e declividade inferior a 3\%. Nesse caso, é necessário apresentar:

- documentação que comprove a dominialidade do terreno, conforme orientações da Instrução Normativa $n^{\circ}$ 001/1997 da Secretaria de Tesouro Nacional;

- $\quad$ Relatório de Vistoria de Terreno (padrão FNDE) subsidiado de fotos;

- Planta baixa onde seja possível verificar as dimensões do terreno, sua planialtimetria (curvas de nível), ruas, confrontações e entorno. Devem constar ainda nessa planta informações sobre norte magnético e ventos dominantes;

b) Apresentação de estudo, embasado em dados oficiais, que comprove a necessidade de construção de escola de ensino infantil na região definida (bairro, setor, conjunto habitacional, etc), levando-se em consideração o número de crianças de zero a seis anos residentes no local, a infra-estrutura existente e a quantidade de crianças sem atendimento.

Ressalta-se que o projeto-padrão disponibilizado tem capacidade de atendimento a 120 crianças em período integral ou até 240 crianças, se distribuídas em turnos matutino e vespertino.

Após aprovação técnica e jurídica dos documentos complementares mencionados para a ação de construção, o FNDE repassará o projeto-padrão de execução, cabendo ao município elaborar o projeto de implantação. Vale salientar que a elaboração do Plano de Trabalho Anual (PTA) está condicionada à aprovação técnica do projeto de implantação.

Depois de se habilitar ao ProInfancia, o município em questão deverá encaminhar solicitação ao FNDE, sob a forma de PTA, em conformidade com as orientações do Manual de Assistência Financeira 2007 do FNDE e do Manual de Orientações Técnicas do ProInfancia.

A transferência de recursos para a execução de projeto aprovado é efetuada por meio de celebração de convênio entre o FNDE e o município ou o Distrito Federal, nos moldes da Resolução nº 6 já citada. 


\subsection{1 - O papel do Fundo Nacional de Desenvolvimento da Educação (FNDE) no PDE}

O FNDE, responsável pela execução do ProInfancia, no âmbito do PDE, foi criado pela Lei $\mathrm{n}^{\circ}$ 5.537, de 21 de novembro de 1968, modificada pelo Decreto-lei $\mathrm{n}^{\circ}$ 872, de 15 de setembro de 1969. É uma autarquia federal vinculada ao MEC que tem como missão prover recursos e executar ações para o desenvolvimento da educação, visando garantir educação de qualidade a todos os brasileiros.

Desde a sua criação, diversas transformações foram implementadas, direcionando esforços tanto para promover impacto imediato no desempenho dos programas, projetos e ações educacionais quanto para melhorar a qualidade de gestão, de modo a adequá-la para atender às mudanças no cenário da política educacional brasileira.

Nesse contexto, o FNDE vem exercendo, nos últimos anos, um papel de destaque no âmbito do MEC, principalmente, quanto à execução do PDE, tanto pelo fato de agregar grande parte do orçamento disponível para a educação básica, como também por se configurar como o executor de várias ações, como o Programa Nacional de Alimentação Escolar (PNAE), o Programa Nacional do Livro Didático (PNLD) e o ProInfancia, entre outros.

Para a execução do ProInfancia foi designada a CGEST, no âmbito da Diretoria de Programas e Projetos Educacionais (Dirpe), à qual compete, de acordo com o Regimento Interno do FNDE: coordenar, acompanhar, supervisionar e avaliar a execução das ações de monitoramento, controle, avaliação e acompanhamento dos programas, projetos e ações afetos à diretoria e executados por parceiros governamentais e não-governamentais, visando ao aprimoramento e à melhoria da gestão e, em especial:

I. Coordenar, acompanhar e supervisionar as atividades relativas à habilitação de órgãos e entidades pleiteantes à assistência financeira para execução de programas, projetos e ações financiadas pelo FNDE;

II. Propor critérios e parâmetros e implantar instrumentos de avaliação dos resultados alcançados pelos programas, projetos e ações da diretoria;

III. Receber, formalizar, protocolar e analisar os documentos de solicitação de assistência financeira (documentação de habilitação e PTA) a programas e projetos educacionais;

IV. Identificar os aspectos formais dos documentos que compõem os processos de habilitação e cadastrar os planos de trabalho;

V. Gerar informações acerca do recebimento e andamento dos pleitos de assistência financeira; 
VI. Articular, no âmbito do FNDE, a elaboração e distribuição de normas, bem como ações de orientação aos proponentes na criação de projetos para assistência financeira;

VII. Orientar os proponentes quanto à elaboração de projetos;

VIII. Cadastrar os projetos educacionais em sistema informatizado, encaminhando-os ao setor pertinente para análise de mérito técnico-pedagógico;

IX. Prestar informações relativas aos PTAs, aos órgãos e às entidades proponentes;

X. Supervisionar, acompanhar e controlar o registro de informações no Cadastro Único Corporativo de Órgãos e Dirigentes e dar suporte aos programas e ações de responsabilidade do FNDE;

XI. Analisar e viabilizar a execução dos programas, projetos e ações decorrentes de resoluções específicas;

XII. Subsidiar a elaboração da proposta orçamentária, acompanhando a execução orçamentária e propondo ajustes no orçamento, no que diz respeito à área de atuação da coordenação-geral; e

XIII. Fornecer subsídios para avaliação técnica nos processos de prestação de contas dos órgãos e entidades beneficiados.

A partir do exercício de 2007, a CGEST passou a ter papel fundamental na execução do ProInfancia como a área responsável pela análise dos processos relativos à assistência financeira ao programa, bem como pela execução das ações de construção e reforma das escolas de educação infantil. A coordenação conta, atualmente, com 22 engenheiros e arquitetos responsáveis pela análise da documentação e pelo acompanhamento da execução das obras, sendo seis profissionais na área de desenvolvimento de novos projetos e 16 na área de análise de projetos, além de outros servidores da parte administrativa.

\subsection{2 - O Sistema Integrado de Monitoramento do Ministério da Educação (Simec)}

Para o acompanhamento da execução do PDE pelo MEC, o FNDE passou a trabalhar também com o Sistema Integrado de Monitoramento do Ministério da Educação (Simec), que é um sistema de informações gerenciais, estruturado de forma a integrar todas as áreas do órgão relativas ao plano, visando consolidar uma gestão eficiente, com indicadores de resultados e parâmetros objetivos para a execução dos programas, ações e projetos educacionais do MEC. 
O Simec atua como instrumento para o processo de planejamento e orçamento, captando informações sobre o andamento dos programas, a fim de subsidiar os dirigentes na tomada de decisões. Funciona, também, como alimentador do Sistema de Informações Gerenciais e de Planejamento (SigPlan) do Ministério do Planejamento, Orçamento e Gestão (MPOG).

\subsection{3 - O atendimento da educação infantil pelo FNDE de 1998 a 2007}

No intuito de se tomar conhecimento do papel exercido pelo FNDE no âmbito da educação infantil, concernente à transferência de recursos mediante convênios, seguem-se informações gerenciais, obtidas no órgão, sobre os repasses ocorridos em um período aproximado de dez anos anteriores ao ProInfancia.

Segundo o Relatório de Atividades do FNDE, no ano de 1998, as ações relativas à educação infantil (pré-escolar) tiveram como objetivo ampliar e melhorar a qualidade do atendimento pedagógico na educação pré-escolar para crianças de quatro a seis anos.

Naquele exercício, a dotação total para essa etapa de ensino foi de 29 milhões de reais, sendo que 5,1 milhões foram destinados para emendas (não executadas) e 18,5 milhões foram distribuídos entre as 26 capitais e o Distrito Federal.

As ações financiáveis eram voltadas para construção e ampliação de escolas, para aquisição de equipamentos e de material didático-pedagógico, além de capacitação de recursos humanos. Foram atendidas 739.461 crianças de quatro a seis anos de 377 municípios.

O Relatório de 1998 traz a ressalva de que a execução de somente 62,7\% da dotação deveu-se aos fatores relativos à queda na arrecadação, o que inviabilizou a assistência financeira a uma série de projetos.

Para o ano de 1999, o mesmo relatório indica que o FNDE teve uma dotação orçamentária de R $\$ 20.444 .973,00$, cuja fonte 113 foi destinada a esse projeto/atividade. Por força de frustração de receita na referida fonte, as ações deixaram de ser executadas naquele exercício.

Em 2000, foram aplicados recursos no montante de R\$14.102.642,00, com o objetivo de se buscar o desenvolvimento integral da criança de até seis anos de idade, em seus aspectos físico, psicológico, intelectual e social, complementando-se a ação da família e da comunidade.

Essas ações coadunavam-se com a política do MEC voltada, essencialmente, à melhoria da qualidade do ensino, quer pela capacitação dos docentes e aquisição de material 
didático para os alunos, quer pelo apoio ao desenvolvimento de projetos pedagógicos norteados por em referenciais curriculares, tendo como base o Referencial Curricular Nacional de Educação Infantil (RCNEI).

No exercício de 2001, a execução financeira abrangeu as ações de formação continuada de professores, com um total de R\$9.845.922,44, e a aquisição e distribuição de material didático-pedagógico, com R\$3.667.199,14.

Objetivando racionalizar o atendimento à clientela demandante dos recursos, o FNDE e a então Secretaria de Educação Fundamental do Ministério da Educação (SEF/MEC) definiram como critérios de aprovação as solicitações dos municípios localizados nas regiões Norte e Nordeste com Índice de Desenvolvimento Humano (IDH) igual a 0,5 ou menor, assim como dos municípios que estivessem operacionalizando os RCNEIs e que integrassem a área de abrangência do Programa Parâmetros em Ação.

A dotação global de 2001 foi executada em 76\%, tendo sido capacitados 25.118 professores de 10.618 escolas, beneficiando 620.263 alunos. Em 2002, foram aplicados R\$14.938.356,54, obedecendo aos mesmos parâmetros definidos para o exercício anterior e contemplando ações similares às do ano de 2001. O relatório não traz mais detalhes sobre as metas alcançadas no exercício.

O Programa Atenção à Criança, assim definido no Plano Plurianual (PPA), no exercício de 2003, tinha como objetivo garantir o direito público de educação infantil a crianças carentes, de zero a seis anos, em instituições educacionais ou organizações nãogovernamentais competentes não apenas para assisti-las e complementar a educação familiar e comunitária, mas também para promover o desenvolvimento integral dessas crianças em seus aspectos físico, cognitivo e psicológico e possibilitar a sua inclusão, com qualidade social, na perspectiva da escola ideal. Os recursos investidos em educação pré-escolar pelo FNDE totalizaram $\mathrm{R} \$ 9.683 .968,29$, nesse ano.

Em 2004, o atendimento à educação infantil deu-se por meio das ações: apoio à distribuição de material didático para a pré-escola; apoio aos projetos municipais para a educação de crianças de até três anos de idade; apoio à capacitação de profissionais nas instituições de educação infantil para crianças de até três anos de idade; apoio à distribuição de material didático para creches e apoio à capacitação de professores da educação infantil.

Ao todo, foram aplicados R $\$ 7.115 .663,76$ de um montante de $\mathrm{R} \$ 15.918 .334,00$, ou seja, as metas financeiras realizadas corresponderam a aproximadamente $45 \%$ do total previsto. A justificativa da não-execução global dos recursos foi de que houve contingenciamento dos mesmos no decorrer do exercício. 
No ano de 2005, foram disponibilizados aproximadamente 16,63 milhões de reais para o cumprimento de cinco ações dentro do Programa Desenvolvimento da Educação Infantil, dos quais foram investidos, efetivamente, 8,59 milhões, o que corresponde a 52\% do total da dotação. Não há justificativa, no relatório, para a não-aplicação do total de recursos previstos; consta, apenas, que a ação Aquisição de Equipamento para a Rede Pública de Educação Infantil não foi realizada por problemas técnicos.

O Relatório de Atividades do FNDE referente ao ano de 2006, antes de iniciar a apresentação da execução das ações relativas à educação infantil, traz algumas considerações sobre essa etapa de ensino, das quais se destaca a seguinte:

\begin{abstract}
Apesar do reconhecimento de sua importância, a educação infantil continua órfã, limitando-se a algumas iniciativas de prefeituras municipais. Os dados estatísticos apresentados sobre esse segmento são preocupantes em relação ao atendimento escolar: apenas $11,7 \%$ das crianças de zero a três anos estão freqüentando creches e 68,4\%, a pré-escola. O problema de insuficiência de oferta, aliado à baixa qualidade do processo educacional e à necessidade de sua universalização, compõe a primeira parte do desafio a ser enfrentado pelo governo federal (FNDE, 2004-2007).
\end{abstract}

Ao se analisar a continuidade do discurso, fica clara a necessidade de se investir mais na educação infantil, por ser, reconhecidamente, uma etapa de ensino em que a taxa de retorno econômico é superior a qualquer outra, além de ser considerada um ponto estratégico para o desenvolvimento socioeconômico do País. Também fica evidenciado que o governo federal tinha consciência desse fato.

O Programa Desenvolvimento da Educação Infantil, em 2006, teve dotação de quase 28 milhões de reais, sendo que, desse montante, investiram-se $\mathrm{R} \$ 18.666 .959,07$, ou seja, o correspondente a $67 \%$ da dotação.

Em 2007, foi implantado o PDE, a partir do qual se busca abandonar a visão fragmentada da educação que desconsiderava níveis, etapas e modalidades como um todo orgânico, em que todas as atenções se voltavam ao ensino fundamental, revertendo esse processo, mediante a implantação do ProInfancia, que tem por objetivo apoiar entidades públicas das esferas federal, estadual, distrital e municipal com recursos financeiros para a renovação da rede física de ensino, incluindo equipamentos, especificamente, para a educação infantil. Para esse exercício, foram disponibilizados 82,27 milhões de reais dos quais foram executados 54,17 milhões, o que corresponde a 66\% da dotação inicial.

A seguir, apresenta-se a Tabela 1, que demonstra a dotação e a execução orçamentária do FNDE no período de 1998 a 2007. 
TABELA 1 - Dotação e execução orçamentárias do FNDE de 1998 a 2007 (em milhões de reais)

\begin{tabular}{c|c|c|c}
\hline Ano & Dotação & Execução & \% \\
\hline 1998 & 29,00 & 18,50 & 63 \\
1999 & 20,44 & 0 & 0 \\
2000 & 14,37 & 14,10 & 98 \\
2001 & 17,83 & 13,51 & 76 \\
2002 & 17,90 & 14,94 & 83 \\
2003 & 17,37 & 9,67 & 56 \\
2004 & 15,92 & 7,12 & 45 \\
2005 & 16,63 & 8,60 & 52 \\
2006 & 27,94 & 18,67 & 68 \\
2007 & 82,27 & 54,17 & 66 \\
\hline
\end{tabular}




\section{6 - ANÁLISE DOS DADOS}

\section{1 - Resultados do ProInfancia}

A partir de pesquisa documental realizada no sítio do FNDE sobre o atendimento pelo ProInfancia, constatou-se que, de 2007 até outubro de 2008, foram beneficiados 892 municípios, com recursos destinados à construção de unidades escolares de educação infantil e ao aparelhamento das mesmas, totalizando R\$632.163.000,00, com o valor básico de 700 mil reais por unidade escolar construída.

Foram pagos, até o momento, $\mathrm{R} \$ 464.499 .000,00$, sendo que esses recursos se referem a convênios firmados em 2007 e 2008. A maioria das obras encontra-se, ainda, em fase de licitação e poucas delas foram acabadas.

Tendo como base dados fornecidos pela área responsável pela execução do ProInfancia, abstraíram-se as informações contidas na Tabela 2, as quais se referem à execução financeira do programa até outubro de 2008:

TABELA 2 - Distribuição de recursos para o ProInfancia em 2007-2008 por região (em milhões de reais)

\begin{tabular}{l|c|c}
\hline \multicolumn{1}{c|}{ Região } & Valor & \% \\
\hline Nordeste & 112,406 & 18 \\
\hline Sul & 149,499 & 24 \\
\hline Sudeste & 264,558 & 42 \\
\hline Centro-Oeste & 89,600 & 14 \\
\hline Norte & 16,100 & 2 \\
\hline Total Brasil & $\mathbf{6 3 2 , 1 6 3}$ & $\mathbf{1 0 0}$ \\
\hline
\end{tabular}

Observa-se que a região Sudeste foi a que recebeu mais recursos (42\%), seguida pela região Sul (24\%); a região Norte, com $2 \%$ dos recursos conveniados, foi a menos beneficiada.

Quanto ao atendimento da educação infantil de modo geral, observou-se que, de 1998 até 2007, não houve repasse de recursos federais destinados à construção de unidades escolares, nem para equipá-las, apesar de, constitucionalmente, estar determinado que a responsabilidade de priorizar essa etapa de ensino é do município. 
Outra constatação é a de que os recursos orçamentários vêm sofrendo contingenciamento ano a ano no âmbito do governo federal, o que se pode aquilatar pelos dados constantes da Tabela 1, já apresentada, referente aos dez anos de atendimento à educação infantil pelo FNDE. Isso redunda em uma constante defasagem no atendimento a essa etapa de ensino.

Com relação à execução financeira do ProInfancia, foram repassados recursos correspondentes a 73\% do montante conveniado. Considerando-se a meta prevista para o ano de 2010 (800 milhões de reais), o total conveniado entre 2007 e 2008 (632,163 milhões de reais) corresponde a 79\% desse valor. Dessa forma, a execução financeira está bastante adiantada, tendo-se em vista que, para se alcançar a meta prevista para 2010, restam apenas $21 \%$ a serem executados.

Veja-se, a seguir, o Gráfico 1, relativo ao repasse em 2007, por região.

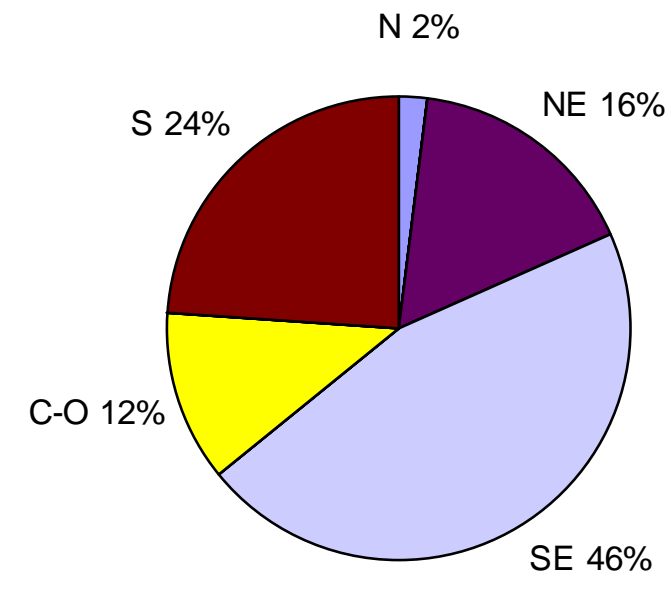

GRÁFICO 1 - Distribuição de recursos para o ProInfancia em 2007 por região (em percentuais)

Quanto ao total de recursos repassados até outubro de 2008, o Gráfico 2 sintetiza a situação: 


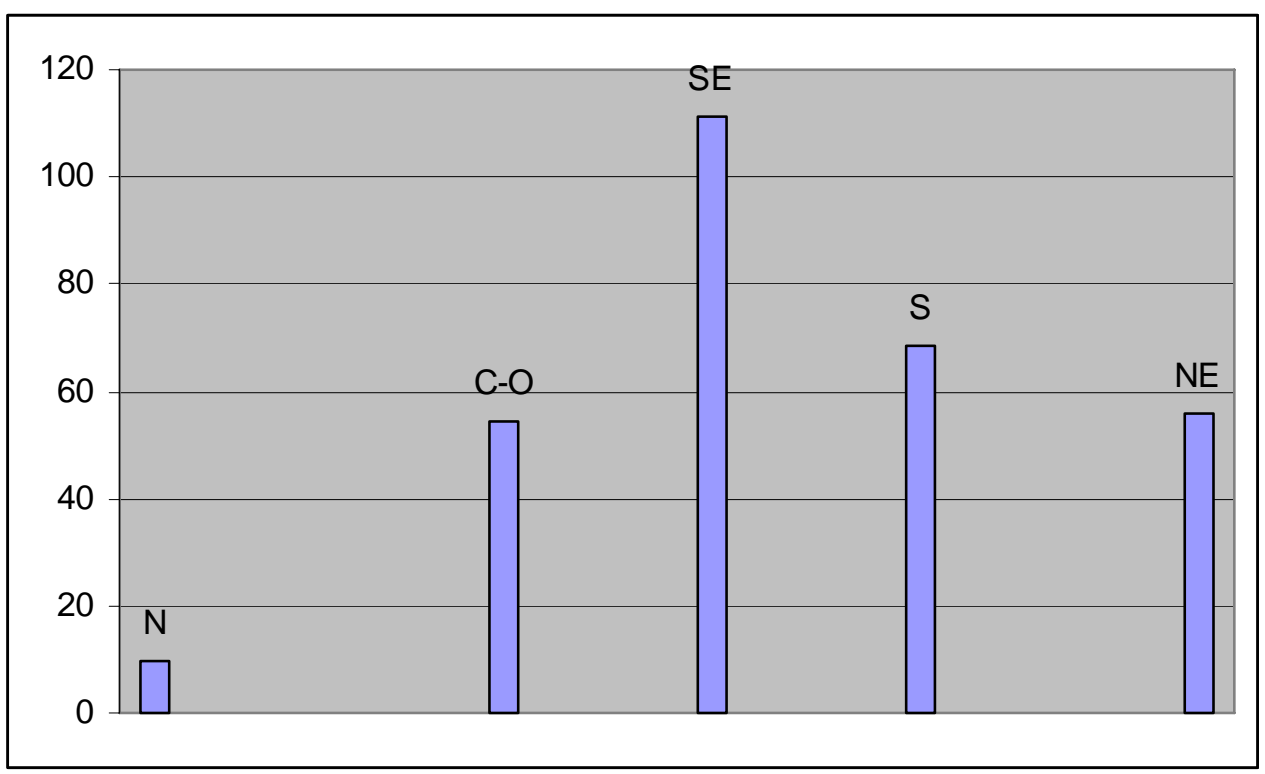

GRÁFICO 2 - Distribuição de recursos para o ProInfancia em 2008 por região (em milhões de reais)

No que se refere à execução física, ocorre o contrário, visto que menos de $1 \%$ das obras foi realizado. Cabe questionar se, em dois anos, será possível concluir todas as obras previstas.

Há que se considerar que os recursos relativos a 2007 não foram repassados logo no início do ano, mas a maior parte no mês de dezembro, ou até em 2008. Além disso, as licitações necessárias à execução das obras costumam demandar tempo, o que atrasa o início das mesmas.

Outra variável a ser pesada é o atraso na entrega da documentação relativa à posse do terreno pelo município, bem como da apresentação do projeto básico. Ou seja, é necessário reavaliar todo o processo nos níveis federal, estadual e municipal, bem como em outros segmentos.

\section{2 - Resultados das Entrevistas}

As entrevistas deste estudo, apresentadas nos Anexos I, II e III, foram conduzidas com o coordenador-geral da CGEST, com um engenheiro da área e com um prefeito de município beneficiado com os recursos do ProInfancia. Para a análise desses instrumentos, as questões foram categorizadas em quatro grupos, conforme o Quadro 2. 
QUADRO 2 - Categorização das questões das entrevistas

\begin{tabular}{|c|c|c|c|c|c|c|c|c|c|c|c|c|c|c|c|c|}
\hline Categorias & q1 & q2 & q3 & q4 & q5 & q6 & q7 & q8 & q9 & q10 & q11 & q12 & q13 & q14 & q15 & q16 \\
\hline PDE & & & & & & & & & & & & & & & & \\
\hline ProInfancia & & & & & & & & & & & & & & & & \\
\hline $\begin{array}{c}\text { Transferências } \\
\text { voluntárias / estrutura de } \\
\text { execução }\end{array}$ \\
\hline \begin{tabular}{c} 
Política educacional \\
\hline
\end{tabular}
\end{tabular}

Foram levantados os seguintes temas vinculados a cada categoria (Quadro 3): 
QUADRO 3 - Temas referentes às categorias

\begin{tabular}{|c|c|}
\hline Categorias & Temas \\
\hline PDE & $\begin{array}{ll}\text { - } & \text { Principais diferenças trazidas pelo plano (q1) } \\
\text { - } & \text { Necessidade de mudanças na execução do plano (q2) } \\
\text { - } & \text { Comprometimento dos atores (estados e municípios) com o plano (q7) } \\
\text { - } & \text { Resistência ao plano por parte dos atores (q8) }\end{array}$ \\
\hline ProInfancia & $\begin{array}{ll}\text { - } & \text { Representatividade do programa para a educação infantil (q3) e (q4)* } \\
\text { - } & \text { Alcance das metas com relação ao planejado (q4) e (q5)* } \\
\text { - } & \text { Efetividade do programa (q5) } \\
\text { - } & \text { Ocorrência de alterações no que foi planejado inicialmente (q6) } \\
\text { - } & \text { Monitoramento/acompanhamento pelo MEC (q15) }\end{array}$ \\
\hline $\begin{array}{l}\text { Transferências } \\
\text { voluntárias / } \\
\text { estrutura de } \\
\text { execução }\end{array}$ & $\begin{array}{ll}\text { - } & \text { Mudanças na forma de atendimento (q10) } \\
\text { - } & \text { Entrega da documentação pelo beneficiário (município) (q14) } \\
\text { - } & \text { Adequação dos sistemas informatizados (q11) } \\
\text { - } & \text { Quantidade e adequação do pessoal disponível para a execução do } \\
& \text { programa (q12) e (q13) }\end{array}$ \\
\hline $\begin{array}{c}\text { Política } \\
\text { educacional }\end{array}$ & $\begin{array}{ll}\text { - } & \text { Critério do menor Ideb para priorização do atendimento (q9) } \\
\text { - } & \text { Cumprimento das metas propostas para o PDE até } 2022 \text { (q16) } \\
\text { - } & \text { Interação entre o MEC, o FNDE e os municípios } \\
\text { - } & \text { Efeitos do PDE no município }\end{array}$ \\
\hline
\end{tabular}

* Questão feita ao prefeito com numeração diferente.

A visão dos entrevistados em relação a cada tema pode ser sintetizada como se segue.

\section{TEMAS RELACIONADOS À CATEGORIA PDE}

\section{- Principais diferenças trazidas pelo plano}

Foi ressaltado o fato de, atualmente, só ocorrer o repasse dos recursos após um planejamento e de que se busca a interação entre as diversas esferas de governo (municipal, estadual e federal), a partir do comprometimento de todos os envolvidos.

\section{- Necessidade de mudança na execução do plano}

Os entrevistados concordam que existe necessidade de mudança no que diz respeito à execução do plano, por exemplo, mais divulgação e recursos a serem aplicados nos programas. 
- Comprometimento dos atores (estados e municípios) com o plano

Os entrevistados são unânimes em afirmar que a idéia foi boa, que a maioria está comprometida, mas declaram que há atores que demoraram a se comprometer ou ainda demonstram, por motivos políticos, a falta de comprometimento com o plano, como é o caso de alguns estados. Na verbalização do prefeito entrevistado: “Não está havendo uma integração boa entre o estado e o município por razões meramente políticas; do ponto de vista da metodologia, nós achamos que há um espaço imenso para interagir e fortalecer mais o processo".

\section{- Resistência ao plano por parte dos atores}

Nas falas de dois dos entrevistados, ficou claro que a maior resistência se deu nos estados, sendo que alguns deles, como é o caso de São Paulo, só assinou o compromisso recentemente. Um dos entrevistados não concorda que houve resistência por parte dos atores.

\section{TEMAS RELACIONADOS À CATEGORIA ProInfancia}

\section{- Representatividade do programa para a educação infantil}

A novidade do estabelecimento de uma política própria para a educação infantil e de parâmetros mínimos para a melhoria dessa etapa de ensino é a grande conquista representada pelo ProInfancia, na opinião dos entrevistados.

\section{- Alcance das metas em relação ao planejado}

Houve divergência nas respostas dos entrevistados quanto a esse tema. Enquanto o coordenador da CGEST afirma que teve dificuldades operacionais e o prefeito que teve dificuldades no início das obras, por problemas de enchentes no município, o engenheiro declara que não houve entraves e que o programa extrapolou as metas previstas para 2007. No entanto, cabe ressaltar que o engenheiro se refere às metas financeiras, ou seja, ao repasse dos recursos, não às metas físicas. 


\section{- Efetividade do programa}

Todos concordam que o programa está sendo efetivo. Entretanto, percebe-se que os entrevistados consideram efetividade como sendo o repasse dos recursos financeiros, o que, na verdade, é eficiência. O prefeito considera que o programa está sendo efetivo por proporcionar a mobilização da sociedade civil em torno da educação.

\section{- Ocorrência de alterações no que foi planejado inicialmente}

Dos entrevistados, dois (coordenador e engenheiro) concordam que houve alterações no modelo inicial da creche-escola a ser construída, sendo que existem, hoje, três modelos, conforme expõe um dos entrevistados: "Então a gente está desenvolvendo uma proposta C, do ProInfancia, com custo reduzido, com um número menor de espaços para atender comunidades do campo". O prefeito afirma que não houve alterações, ainda, tendo em vista que seu município só recebeu os recursos recentemente, estando o programa ainda em fase de “implantação”.

\section{- Monitoramento/acompanhamento pelo MEC}

Segundo os entrevistados representantes do FNDE, existem sistemas que já sinalizam o monitoramento, porém, quanto ao acompanhamento, está sendo estruturada uma área especialmente para isso. O prefeito entrevistado diz desconhecer esse assunto, pois o mesmo é de responsabilidade de sua Secretaria de Educação Municipal.

\section{TEMAS RELACIONADOS À CATEGORIA TRANSFERÊNCIAS VOLUNTÁRIAS / ESTRUTURA DE EXECUÇÃO}

\section{- Mudanças na forma de atendimento}

Os entrevistados destacam a mudança de paradigma no atendimento nos moldes do PDE, em que: 
a) Houve uma evolução ao longo do tempo, passando-se a fazer um levantamento das necessidades por meio do Sistema de Levantamento da Situação Educacional (LSE);

b) Os municípios beneficiados não são mais os que têm maior engajamento político ou maior capacidade técnica, mas, sim, os mais necessitados da ajuda do governo federal (Obs.: esta questão não foi feita ao prefeito).

\section{- Entrega da documentação pelo beneficiário (município)}

Destaca-se a falta de capacidade técnica dos municípios como um entrave quando da entrega da documentação exigida, apesar de a padronização dos documentos da obra ser um fator de facilitação para os municípios. Porém, a comprovação, pelo município, da dominialidade dos terrenos onde serão construídas as escolas é um problema histórico, mas está sendo sanado com a ajuda da Procuradoria Jurídica do FNDE.

\section{- Adequação dos sistemas informatizados}

Sobre esse tema, os entrevistados registram:

a) A inevitabilidade e a necessidade do uso dos sistemas, como também a existência de uma equipe técnica treinada na base para dar suporte aos municípios;

b) A necessidade de se aperfeiçoarem os sistemas e de se capacitar a equipe técnica disponível;

c) A necessidade de melhoria nos sistemas (Obs.: questão não apresentada ao prefeito).

\section{- Quantidade e adequação do pessoal disponível para a execução do programa}

Segundo os entrevistados, o pessoal “da ponta”, ou seja, dos estados e municípios, não é suficientemente treinado e o FNDE já está providenciando esta capacitação in loco sobre o programa. Outra questão lembrada foi a rotatividade do pessoal, o que atrapalha o andamento das ações. Na opinião do prefeito, o seu município não tem muito problema nessa área por contar com a ajuda da universidade estadual para a capacitação do seu pessoal, sempre que precisa. 


\section{TEMAS RELACIONADOS À CATEGORIA POLÍTICA EDUCACIONAL}

\section{- Critério do menor Ideb para priorização do atendimento}

Sobre esse tema, os entrevistados enfatizam o avanço com relação à criação de um índice somente para a educação, sendo este um critério mais justo e de fácil entendimento. Entretanto, já surge na fala de um dos entrevistados a possibilidade de se rever esse índice a médio prazo, tendo-se em vista questões não abarcadas pelo Ideb, como é o caso de um parâmetro para a educação infantil.

\section{- Cumprimento das metas propostas para o PDE até 2022}

Os entrevistados são unânimes em afirmar que as metas propostas para o PDE podem ser cumpridas, conforme foi planejado, até 2022. Porém, como o programa está apenas no início, observa-se que a opinião dos entrevistados está baseada no sentimento de esperança, não em dados concretos.

\section{- Interação entre o MEC, o FNDE e os municípios}

Os entrevistados declaram que essa parceria iniciada com o PDE vem dando certo e vai levar a “uma efetividade maior na ponta”.

\section{- Efeitos do PDE no município}

Este foi um tema que apareceu em uma das respostas dadas pelo prefeito, em que ele destaca que o plano tem proporcionado uma mobilização em torno da educação jamais vista no município, envolvendo o Ministério Público, as entidades civis e o Conselho Municipal de Infância, os quais participam ativamente das decisões sobre educação, na localidade. 


\section{7 - CONSIDERAÇÕES FINAIS}

A elaboração de políticas públicas no Brasil, tradicionalmente, tem sido alvo de críticas, por serem construídas a partir de uma visão limitada a estudos técnicos governamentais, que, muitas vezes, desconsideram a opinião da população interessada e alcançada por essas políticas.

Entretanto, o governo federal, com o PDE, faz vislumbrar um novo formato, uma proposta inovadora para a política educacional, por meio da qual pretende retomar os objetivos e as metas do PNE. Com base em uma visão sistêmica do ensino e tendo a educação como um processo, busca, a partir do comprometimento de toda a sociedade, a eqüidade e a qualidade da educação pública, atendendo, assim, os anseios das populações mais carentes de ajuda.

Após uma breve reflexão sobre as políticas educacionais e da apresentação das bases filosóficas do PDE, esta pesquisa destacou o ProInfancia, programa do PDE que, indiscutivelmente, representa um resgate da educação infantil, suprindo uma de suas necessidades históricas: ampliação da infra-estrutura física e de equipamentos para escolas.

Ressalta-se a importância desse programa, visto que essa etapa de ensino deixou de ser priorizada durante décadas, em favor, principalmente, do ensino fundamental, cuja universalização era considerada prioritária. Em vista disso, a educação infantil sofreu, durante anos, com o contingenciamento dos recursos que seriam destinados ao atendimento de sua clientela.

O período delimitado para o estudo foi a partir de 2007, ano da implantação do ProInfancia, até outubro de 2008, época de finalização da pesquisa.

Dentre os principais resultados podem-se destacar os seguintes: a constatação do adiantado estágio da execução financeira, enquanto que a execução física está no estágio inicial, devido a questões operacionais, como o repasse de recursos no final do exercício de 2007; questões relativas à licitação das obras; atraso na entrega da documentação pelo município.

Outro fator que claramente atrapalhou a evolução do programa foi a resistência de alguns dos parceiros em aderir ao Compromisso Todos pela Educação, que representa a base para o sucesso do PDE.

A promoção da eqüidade no atendimento, no que diz respeito ao repasse de recursos, por região, ainda não é transparente, tendo-se em vista que a região Sudeste continua 
recebendo a maior quantidade de aporte financeiro, enquanto a região Norte é a que menos tem recebido. A região Nordeste aparece em terceiro lugar.

Quanto aos avanços trazidos pelo PDE e, conseqüentemente, pelo ProInfancia, podem-se citar as mudanças na forma de atendimento às transferências voluntárias mediante convênio, por intermédio do que se faz um diagnóstico anterior à liberação dos recursos ou de assistência técnica. Isso representou ganhos no que se refere à justiça e, por que não dizer, à moralização no repasse de recursos pelo MEC.

A constante preocupação dos gestores do programa com a adequação dos prédios escolares à real necessidade da população, visando a economicidade da obra, é algo importante constatado neste trabalho. Dessa forma, torna-se menor o risco de se construírem obras faraônicas e com a possibilidade de serem abandonadas.

Sabe-se que, assim como os seres humanos evoluem, suas instituições também evoluem. Isso ocorre com a política e, conseqüentemente, com a forma de se fazer política e políticas públicas. Nesse contexto, percebe-se que o ProInfancia decorre dessa evolução e tem grandes contribuições a oferecer, desde que se prime pelo seu monitoramento por parte do MEC e do FNDE. É oportuno lembrar que o convênio não acaba com a sua assinatura: pelo contrário, então é que começa.

Os agentes públicos precisam ter em mente que o ambiente educacional é algo muito importante, mas não é tudo. É parte de um processo que inclui: pessoal capacitado e valorizado, condições materiais, estrutura pedagógica adequada e voltada para a transformação da realidade pela educação, uma educação de qualidade.

O fantasma da descontinuidade das políticas públicas tem que ser vencido. Os Centros Integrados de Educação Pública (CIEPs), os Centros de Atenção Integral à Criança (CAICs), a Escola Básica Ideal, por exemplo, são ícones desse problema. São modelos de estruturas físicas para a educação que tinham por trás de si pensamentos e ideais considerados válidos, à época, e que, no entanto, foram abandonados após a sucessão de seus idealizadores.

É preciso contar com a mudança de cultura da nossa sociedade, de modo que o planejamento passe a fazer parte de todas as ações dos governos e haja articulação entre os entes governamentais para a definição das políticas a serem adotadas. Essa articulação fará com que o compromisso seja algo natural e com que todos trabalhem para um mesmo fim: a educação pública de qualidade. Faz-se necessário sair do compromisso com o discurso pautado pela legislação e partir para a prática realizadora. 


\section{8 - CONTRIBUIÇÕES E SUGESTÕES}

Como resultado deste estudo, sugere-se que não se deixe morrer a idéia contida na formulação do PDE e no ProInfancia de se darem à educação infantil as condições necessárias às crianças, as quais representam, verdadeiramente, o futuro do nosso País e merecem uma escola digna e, no mínimo, a atenção que é dada ao ensino fundamental e ao superior.

Em segundo lugar, partindo de uma fala do coordenador da CGEST, em entrevista para este trabalho, sugere-se que o ministério considere a possibilidade de aperfeiçoar o Ideb ou, se for o caso, de criar outro índice capaz de suprir as necessidades já constatadas, em conseqüência de avaliações já efetivadas.

De igual importância seria que todos os entes da Federação fizessem uma reflexão conjunta sobre a necessidade de se articularem, em detrimento de questões políticas, quando da formulação de políticas públicas nacionais, partindo da base para o ápice e tendo o compromisso de todos como fundamento essencial para as decisões. Nas palavras do prefeito entrevistado: “Se não houver um avanço significativo no processo educacional, inclusive o desenvolvimento econômico do País pára...”.

Finalmente, ressalta-se a expectativa de que este estudo possa servir de incentivo para a realização de outras pesquisas mais amplas sobre o assunto abordado. 


\section{REFERÊNCIAS}

AFONSO, A. J. Estado, globalização e políticas educacionais: elementos para uma agenda de investigação. Revista Brasileira de Educação, Rio de Janeiro, n. 22, jan./fev./mar./abr. 2003.

AZEVEDO, J. M. L. de. A educação como política pública. 3. ed. São Paulo: Autores Associados, 2004.

BARRETO, A. M. R. F. A educação infantil no contexto das políticas públicas. Revista Brasileira de Educação, Rio de Janeiro, n. 24, p. 53-65, 2003.

BRASIL. Ministério da Educação. Fundo Nacional de Desenvolvimento da Educação (FNDE). Regimento Interno. Portaria ${ }^{\circ}$ 1.133, de 27 de novembro de 2007.

Relatórios de Atividades 2004-2007. Brasília.

Lei de Diretrizes e Bases da Educação Nacional. Brasília, 1996.

programas. Brasília, 2008.

O Plano de Desenvolvimento da Educação (PDE): razões, princípios e

Plano Nacional de Educação (PNE). Brasília, 2001.

. Secretaria de Educação Especial. Documento subsidiário à política de inclusão. Brasília: Seesp, 2007.

DEMO, P. A nova LDB: ranços e avanços. 6. ed. Campinas: Papirus, 1998, p. 67-89.

GIL, Antonio Carlos. Como elaborar projetos de pesquisa. 4. ed. São Paulo: Atlas, 2002.

HUNT, E. K. História do pensamento econômico: uma perspectiva crítica. 7. ed. Rio de Janeiro: Campus, 1981, p. 41-43.

IBGE. Censo Demográfico, ano 2008. Disponível em: <http://www.ibge.gov.br/Home/ estatística/população/censo2008/defaut.shtm>. Acesso em: 8 jul. 2008.

KUHLMANN JR., M. Educando a infância brasileira. In: LOPES, E. M. T.; FARIA FILHO, L. M. 500 anos de educação no Brasil. 2. ed. Belo Horizonte: Autêntica, 2000, p. 470.

MACPHERSON, C. B. A democracia liberal: origens e evolução. Rio de Janeiro: Zahar, 1978.

MATIAS-PEREIRA, J. Manual de metodologia da pesquisa científica. São Paulo: Atlas, 2007.

SAVIANI, D. A nova lei da educação - LDB: trajetória, limites e perspectivas. 1. ed. Campinas: Autores Associados, 1997, p. 199-220.

SPINK, P. (Org.). Reforma do estado e administração pública gerencial. 1. ed. Rio de Janeiro: Getulio Vargas, 1998, p. 75-121. 


\begin{abstract}
ANEXO I
ROTEIRO DE ENTREVISTA SEMI-ESTRUTURADA SOBRE A TEMÁTICA: “A política educacional implementada pelo Plano de Desenvolvimento da Educação”, a ser aplicada ao coordenador-geral da área, no FNDE, responsável pela coordenação da execução do ProInfancia, na CGEST.
\end{abstract}

1. Quais as principais diferenças trazidas pelo PDE, como política educacional, do ponto de vista da atuação do MEC e do FNDE?

2. O que você acha que poderia ser mudado, com vistas a facilitar a execução do PDE?

3. O que representa o ProInfancia para a educação infantil no Brasil?

4. Qual o alcance do ProInfancia com relação às metas previstas para 2007? Houve dificuldades para isso?

5. Na sua opinião, o programa/ação está sendo efetivo e desenvolvido conforme o planejado?

6. Houve alteração em relação ao planejamento inicial do programa e o que está sendo efetivamente executado? Em caso afirmativo, exemplificar.

7. Como você sabe, um dos pilares do PDE é o comprometimento de todos os parceiros (municípios, estados, o Distrito Federal, entre outros). Nesse sentido, como está sendo o comprometimento? Poderia melhorar?

8. Você está percebendo alguma resistência/oposição (qual?) ao plano por parte de algum(ns) ator(es) envolvido(s)? (quais?)

9. O critério do menor Ideb, adotado pelo governo federal como parâmetro de priorização dos municípios a serem atendidos, é adequado? Poderia ser outro?

10. Até 2006, o atendimento referente às transferências voluntárias tinha uma forma diferenciada do PDE, em que o interessado apresentava seu projeto e, desde que este estivesse dentro dos parâmetros da resolução relativa ao programa, seria ou não atendido. $\mathrm{O}$ que você acha dessa nova forma de atendimento nos moldes postos pelo PDE?

11. Quanto aos sistemas informatizados, estão atendendo as demandas exigidas para a execução dos programas? Se não, o que poderia ser feito para melhorar essa situação?

12. Com relação ao quantitativo de pessoal, é suficiente para o bom desenvolvimento do programa?

13. O pessoal que executa as ações é treinado adequada e suficientemente? Se não, o que falta para que isso aconteça?

14. Como está a interação entre o FNDE, o MEC e os municípios para a execução do ProInfancia? Poderia melhorar? Em que sentido?

15. Já foi realizado algum acompanhamento do programa? Em caso afirmativo, qual o resultado?

16. De acordo com o cenário atual, você considera que há possibilidade de o governo alcançar as metas propostas para o PDE até 2022, ou seja, atingir resultados de um sistema educacional de qualidade equivalente ao dos países desenvolvidos? 


\begin{abstract}
ANEXO II
ROTEIRO DE ENTREVISTA SEMI-ESTRUTURADA SOBRE A TEMÁTICA: “A política educacional implementada pelo Plano de Desenvolvimento da Educação” a ser aplicada a um técnico (engenheiro) lotado na CGEST.
\end{abstract}

1. Quais as principais diferenças trazidas pelo PDE, como política educacional, do ponto de vista da atuação do MEC e do FNDE?

2. O que você acha que poderia ser mudado, com vistas a facilitar a execução do PDE?

3. O que representa o ProInfancia para a educação infantil no Brasil?

4. Qual o alcance do ProInfancia com relação às metas previstas para 2007? Houve dificuldades para isso?

5. Na sua opinião, o programa/ação está sendo efetivo e desenvolvido conforme foi planejado?

6. Houve alteração em relação ao planejamento inicial do programa e o que está sendo efetivamente executado? Em caso afirmativo, exemplificar.

7. Como você sabe, um dos pilares do PDE é o comprometimento de todos os parceiros (municípios, estados, o Distrito Federal, entre outros). Nesse sentido, como está sendo o comprometimento? Poderia melhorar?

8. Você está percebendo alguma resistência/oposição (qual?) ao plano por parte de algum(ns) ator(es) envolvido(s)? (quais?)

9. O critério do menor Ideb, adotado pelo governo federal como parâmetro de priorização dos municípios a serem atendidos, é adequado? Poderia ser outro?

10. Até 2006, o atendimento referente às transferências voluntárias tinha uma forma diferenciada do PDE, em que o interessado apresentava seu projeto e, desde que este estivesse dentro dos parâmetros da resolução relativa ao programa, seria ou não atendido. $\mathrm{O}$ que você acha dessa nova forma de atendimento nos moldes postos pelo PDE?

11. Quanto aos sistemas informatizados, estão atendendo as demandas exigidas para a execução dos programas? Se não, o que poderia ser feito para melhorar essa situação?

12. Com relação ao quantitativo de pessoal, é suficiente para o bom desenvolvimento do programa?

13. O pessoal que executa as ações é treinado adequada e suficientemente? Se não, o que falta para que isso aconteça?

14. Como está a interação entre o FNDE, o MEC e os municípios para a execução do ProInfancia? Poderia melhorar? Em que sentido?

15. Já foi realizado algum acompanhamento do programa? Em caso afirmativo, qual o resultado?

16. De acordo com o cenário atual, você considera que há possibilidade de o governo alcançar as metas propostas para o PDE até 2022? 


\begin{abstract}
ANEXO III
ROTEIRO DE ENTREVISTA SEMI-ESTRUTURADA SOBRE A TEMÁTICA: “A política educacional implementada pelo Plano de Desenvolvimento da Educação” a ser aplicada a um prefeito de município beneficiado pelo programa.

1. Quais as principais diferenças trazidas pelo PDE, como política educacional, do ponto de vista da atuação do MEC e do FNDE no atendimento aos municípios?

2. O que você acha que poderia ser mudado, com vistas a facilitar a execução do PDE?

3. Você está percebendo alguma resistência/oposição (qual?) ao plano por parte de algum(ns) ator(es) envolvido(s)? (quais?)

4. Qual a importância do ProInfancia para o município?

5. Qual o alcance do ProInfancia com relação às metas previstas para 2007? Houve dificuldades para isso?

6. A(s) unidade(s) de ensino que está(estão) sendo construída(s) ou reformada(s) vai(vão) atender toda a demanda de alunos da educação infantil do município?

7. Com relação ao quantitativo de pessoal para o trabalho nessas unidades, é suficiente? O pessoal é capacitado?

8. Seria necessário que o ProInfancia oferecesse algo mais ao município para que as unidades de ensino funcionassem melhor?

9. Como está a interação entre o FNDE, o MEC e os municípios para a execução do ProInfancia? Poderia melhorar? Em que sentido?

10. Na sua opinião, o programa está sendo efetivo e desenvolvido conforme foi planejado?

11. Como você sabe, um dos pilares do PDE é o comprometimento de todos os parceiros (municípios, estados, o Distrito Federal e a União, entre outros). Nesse sentido, como está sendo o envolvimento de cada um deles? Poderia melhorar?

12. Já foi realizado algum acompanhamento do programa? Em caso afirmativo, qual o resultado?

13. Houve alteração em relação ao planejamento inicial do programa e o que está sendo efetivamente executado? Em caso afirmativo, exemplificar.

14. De acordo com o cenário atual, você considera que há possibilidade de o governo alcançar as metas propostas para o PDE até 2022?
\end{abstract}

